\title{
Inventory of Plants, Plant Communities and Herpetofauna of Concern in the Vicinity of the Snow-Talon Burn, Helena National Forest
}

\author{
Prepared for: \\ Helena National Forest \\ 2880 Skyway Drive \\ Helena, Montana 59602
}

By:

Stephen V. Cooper, Gregory M. Kudray, Paul Hendricks, Bryce A. Maxell, W. Marc Jones, Coburn Currier and Susan Lenard

Montana Natural Heritage Program

Natural Resource Information System

Montana State Library

December 2005

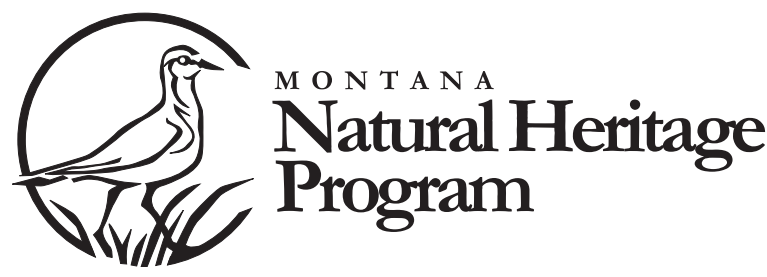





\title{
Inventory of Plants, Plant \\ Communities and Herpetofauna of \\ Concern in the Vicinity of the \\ Snow-Talon Burn, Helena \\ National Forest
}

\author{
Prepared for: \\ Helena National Forest \\ 2880 Skyway Drive \\ Helena, Montana 59602
}

Agreement Number:

03-CS-11011200-007

By:

Stephen V. Cooper, Gregory M. Kudray, Paul Hendricks, Bryce A. Maxell,

W. Marc Jones, Coburn Currier, and Susan Lenard
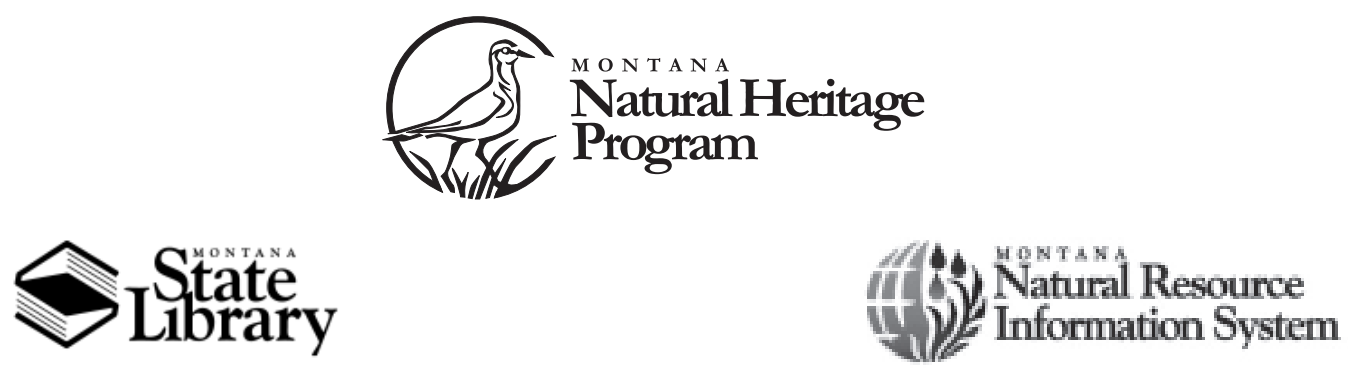

(C) 2005 Montana Natural Heritage Program

P.O. Box 201800 • 1515 East Sixth Avenue • Helena, MT 59620-1800 • 406-444-5354 
This document should be cited as follows:

Cooper, S.V., G. M. Kudray, P. Hendricks, B.A. Maxell, Jones, W. M., C. Currier, and S. Lenard 2005. Inventory of Plants, Plant Communities, and Herpetofauna of Concern in the Vicinity of the Snow-Talon Burn, Helena National Forest. Report to the Helena National Forest. Montana Natural Heritage Program, Helena, MT. 15 pp. plus appendices. 


\section{Executive Summary}

Montana Natural Heritage Program (MTNHP)

biologists inventoried sensitive vascular plants, riparian and wetland associated plant communities, and herpetofauna near and within the Snow-Talon Fire of 2003 on the Helena National Forest. Appropriate habitat was searched for 14 vascular plant species of concern that are potentially present in the area, however, none were encountered. Ninety percent of the twenty sites had herpetofauna with four amphibian species (Longtoed Salamander, Rocky Mountain Tailed Frog, Western Toad, and Columbia Spotted Frog) and two reptile species (Terrestrial Gartersnake and Common Gartersnake) recorded. Detections of the Western Toad, a Montana Species of Concern as well as a U.S. Forest Service Northern Region Sensitive Species (MTNHP 2004), were noteworthy and encouraging. It was breeding in all four drainages surveyed, indicating that a relatively large population is now in the area and is possibly expanding because of the fire and the Western Toad preference for disturbed forest and wetland habitats. This is especially significant given declining trends for this species elsewhere in western Montana during the last 50 years. We recommend monitoring of Western Toad populations in the area and systematic surveys of stream habitats in order to better document the distribution and status of Rocky Mountain Tailed Frogs in the area; there is only one record in this locale other than the two sites we found.

Detailed vegetation surveys were conducted at several wetland and riparian sites. Baseline early post-burn vegetation data will enable further monitoring of the effects of wildfire on vegetation and herpetofauna habitat in these important ecosystems. About half of the 50 potentially occurring riparian and wetland plant communities having a rank of G3, S3, or less were documented.
Generally, these sites were ecologically intact and represented important habitat in this relatively arid environment. A few sites are unique and the diversity of wetland plant communities is considerable.

One large wetland (Copper Creek, Lower Drainage site) contained an extensive carr, a type of fen, which is a very uncommon community type in Montana. This site has an extensive bryophyte component and warrants further survey for this taxonomic group. At Porcupine Basin we putatively identified the easternmost documentation of Northern licorice-root, a species more typically found in mesic northern Idaho. The lack of seeds for a positive identification suggests that another visit at the appropriate time would be worthwhile, as this would be a considerable range extension.

Keep Cool Lakes has a community type that may have once been a species-rich blue wildrye meadow, a G2 rank community previously known only from California and Oregon. Nonnative timothy grass now dominates. Keep Cool Lakes is still an intact and diverse wetland, but typifies a problem often encountered when ATV use occurs in these open and easily accessible types.

Nonnative species were invading along the disturbed track, one vegetation type was degraded, and large disturbances were created where ATVs had to be extricated from wetter areas. Western toads were breeding here and ATV tracks were noted within a few feet of where toads were depositing egg strings.

The ecological integrity of this site and most other accessible wetlands will be threatened if the disturbance and resultant weed infestation and habitat degradation from ATV use continue. 


\section{ACKNOWLEDGMENTS}

The work described in this report was funded primarily through Challenge Cost Share Agreement No. 03-CS-11011200-007 between the Helena National Forest and the Nature Conservancy's Montana Natural Heritage Program. We are particularly grateful to Lois Olsen of the Helena National Forest for her interest in evaluating the status of wetland habitats and wetland dependent species on the Helena National Forest. We would also like to acknowledge the Region 1 Office of the US Forest Service for their continued support of the statewide amphibian inventory program; data from this project is included in the report. 


\section{TABLe OF Contents}

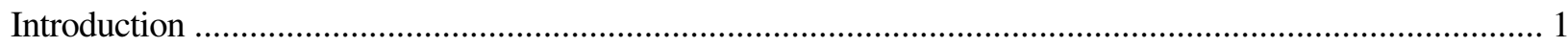

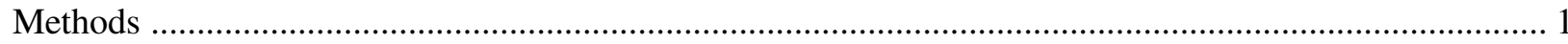

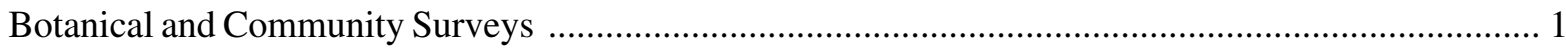

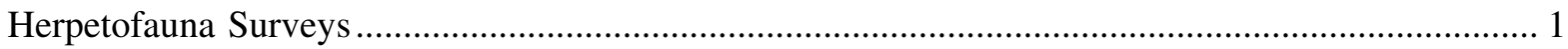

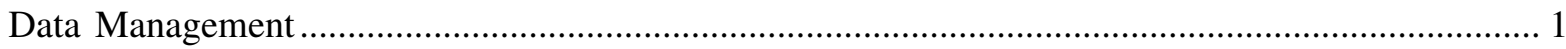

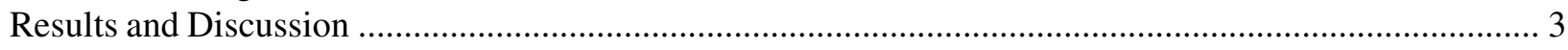

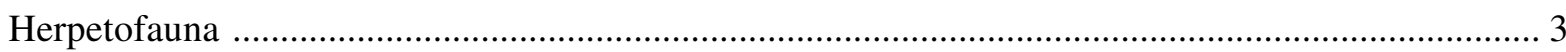

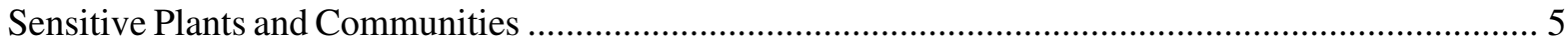

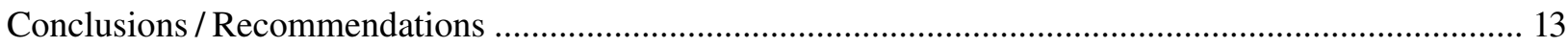

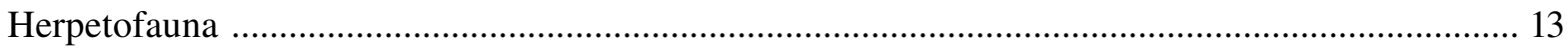

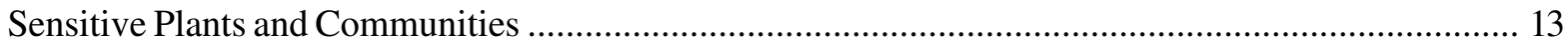

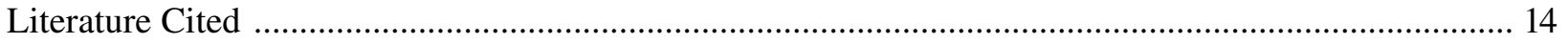

\section{List OF Figures}

Figure 1. Study area and ecological survey areas in the vicinity of the Snow-Talon burn ........................ 2

Figure 2. Wetlands surveyed for herpetofauna in 2004 and 2005 .................................................... 4

Figure 3. ATV track through Keep Cool Lake wetlands .................................................................. 9

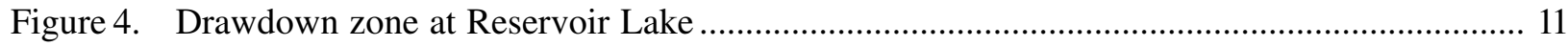

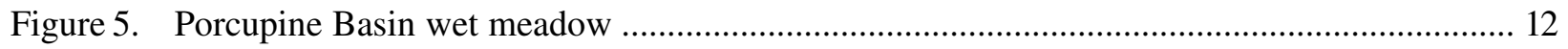

Appendix A. Global/State Rank Definitions

Appendix B. Tables

Table 1. Inventory targets for plant species of concern and highly ranked plant communities

Appendix B - 1

Table 2. Amphibian and reptile species detected during wetland site surveys Appendix B - 2

Appendix C. Occurrence Maps of Herpetofauna

Figure 1. Long-toed Salamander (Ambystoma macrodactylum)

Appendix C - 1

Figure 2. Rocky Mountain Tailed Frog (Ascaphus montanus) Appendix C - 2

Figure 3. Western Toad (Bufo boreas) Appendix C - 3

Figure 4. Columbia Spotted Frog (Rana luteiventris) Appendix $\mathrm{C}-4$

Figure 5. Terrestrial Gartersnake (Thamnophis elegans) Appendix C - 5

Figure 6. Common Gartersnake (Thamnophis sirtalis)...... Appendix C - 6 



\section{INTRODUCTION}

The summer of 2003 was an extreme fire year throughout the western US and western Montana, where one extensive fire, the Snow-Talon, occurred on the Helena National Forest near Lincoln (Figure 1). The USFS contracted with the Montana Natural Heritage Program to conduct a survey to gauge the impact of the fire on some of the wetland systems and a selected portion of their biota. Another objective was to understand the diversity of wetlands within a core area that included the burned area as well as some outlying sites. This survey can serve as a baseline to help predict fire effects on herpetofauna in similar ecosystems and to evaluate post fire succession.

\section{MeTHODS}

We conducted surveys in the late spring and summer of 2004 and 2005 that were focused on plant and amphibian species of concern (Appendix B Tables 1 and 2) and priority vegetation types (plant associations) associated with wetland/ riparian habitats. Lois Olsen, Ecologist for the Helena National Forest, made informed suggestions as to which drainages and wetlands were of highest potential interest.

\section{Botanical \& Community Surveys}

We compiled a list (Appendix B Table 1) of highly ranked communities, those with a Global $(\mathrm{G})$ or State (S) rank of 3 or less or where S-rank was currently undetermined (Grossman et al. 1998, Anderson et al. 1998). Forest Service Sensitive plant species (Appendix B Table 1) likely to occur in the study area were also identified. Further information on these plants and communities can be obtained from the Montana Natural Heritage Program's web site, www.mtnhp.org and "Plant Species of Concern" by the Montana Natural Heritage Program (2003). In the field, we sampled vegetation communities by structure and composition with emphasis on dominants and indicator species. Vegetation keys and descriptions (Pfister et al. 1977, Hansen et al. 1995) were consulted to verify vegetation associations at sites. Some communities did not key to or match descriptions in either of the above references.
When this was the case, we then consulted the EcoART database (ABI 2000) and attempted to match communities to those in the database.

\section{Herpetofauna Surveys}

Sites for amphibian surveys were identified through discussions with the Heritage Program wetland ecologist, Helena National Forest personnel, and study of USGS 7.5' topographic maps. Marshes, small ponds and lakes, and selected stream reaches in the study area, all of which were north of Lincoln on Helena National Forest lands in Lewis and Clark and Powell counties, were priority sites for surveys.

Shorelines and wetland margins were searched for adults and juveniles while walking along the edge. The entire perimeter was searched at some sites, others were inspected by traversing the length of the site through shallow emergent vegetation, or along selected portions of the margin where emergent vegetation or other cover was present. June surveys included visual searches for egg masses attached to submerged and emergent vegetation or egg strings in shallow open water. At regular intervals, and where appropriate, the aquatic habitat was sampled for larvae using a dipnet.

Time of day and duration of searches (a measure of search effort: Heyer et al. 1994, Olson et al. 1997), weather, water temperature, and species encountered were recorded on standard U.S. Fish and Wildlife Service data sheets. Duration of site surveys ranged from 9-300 minutes (Appendix B Table 2), and depended upon the size and structural complexity of each site, site conditions (including weather), and findings. A team of two or three persons conducted each survey.

\section{Data Management}

New data collected on amphibians, plant species of concern, and high quality vegetation communities were georeferenced, digitized and documented as element occurrence records in the databases maintained by the Montana Natural Heritage Program. Plot data and summary information on noteworthy sites were also entered into MTNHP 


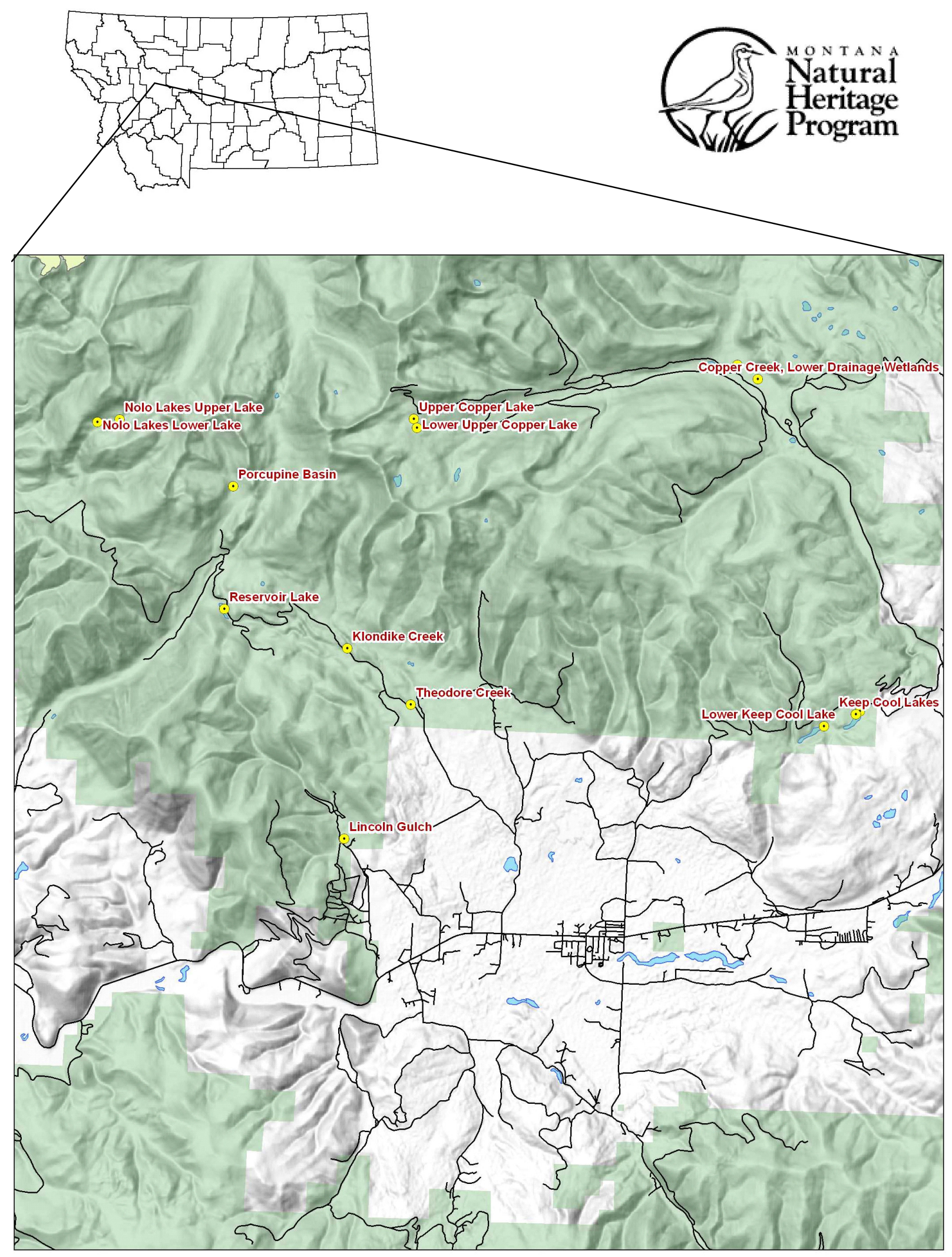

Figure 1. Study area and ecological survey areas near the Snow-Talon burn 
databases. This data system serves as the primary source of information on the status and distribution of Montana's native species and habitats.

\section{Results AND Discussion}

\section{Herpetofauna}

In 2004 we conducted 20 site surveys for amphibians (Figure 2, Appendix B Table 2) in the drainages of Beaver Creek (sites 11, 19-20), Copper Creek (sites 8-10, 14-18), Keep Cool Creek (sites 1-2), and Landers Fork (sites 3-7, 1213). Sites ranged in elevation from $4900 \mathrm{ft}$ to 7220 $\mathrm{ft}$ and were surveyed during 1-4 June or 8-9 September; all sites were visited only once. In 2005, 7 of these sites were resurveyed and an oxbow on the Blackfoot River (site 21) was also surveyed because of previous records of Western Toad breeding activity at these locations (Figure 2 \& Appendix C Figure 5, Appendix B Table 2). Four amphibian species (Long-toed Salamander, Rocky Mountain Tailed Frog, Western Toad, Columbia Spotted Frog) and two reptile species (Terrestrial Gartersnake and Common Gartersnake) were detected during the surveys. No amphibians or reptiles were found at two (10\%) of the sites we surveyed. The most commonly observed amphibian during our 2004 surveys was the Columbia Spotted Frog, detected at 13 sites. The Rocky Mountain Tailed Frog was found at two sites, the Long-toed Salamander at one site, the Terrestrial Gartersnake at one site, and the Common Garter Snake at one site. The Western Toad was detected at nine sites in 2004 and detected breeding at 5 of the 8 sites resurveyed in 2005 when they were the focus of survey effort.

We found evidence of breeding in the study area by four of the amphibian species detected in both 2004 and 2005: Long-toed Salamander at one site (5\%) in 2004 and five sites (63\%) in 2005, Rocky Mountain Tailed Frog at the only two sites (100\%) surveyed in 2004 which had suitable habitat present, Western Toad at five sites (25\%) in 2004 and five sites (63\%) in 2005, and Columbia Spotted Frog at ten sites (50\%) in 2004 and three sites (38\%) in 2005 (Appendix B Table 2, Figure 2, Appendix C Figures 1-6). Long-toed Salamanders,
Western Toads, and Columbia Spotted Frogs were documented breeding in each of the four drainages we sampled as well as at the oxbow on the Blackfoot River. Rocky Mountain Tailed Frogs were detected only in the Beaver Creek drainage. However, this was the only drainage where suitable stream habitats were surveyed. As indicated by the presence of another observation of the species on a tributary to Copper Creek in 1966, it seems likely that additional surveys of suitable stream habitats would reveal their presence throughout much of the area.

During the 2004 surveys, we found all native amphibian species expected in the study area. Three additional native amphibian species found in Montana west of the Continental Divide, Coeur d'Alene Salamander (Plethodon idahoensis), Pacific Treefrog (Pseudacris regilla) and Northern Leopard Frog (Rana pipiens), have not yet been reported from either Powell or Lewis and Clark counties (Maxell et al. 2003, Werner et al. 2004).

Of the four amphibian species present, the Western Toad is a Montana Species of Concern, as well as a U.S. Forest Service Northern Region Sensitive species (Montana Natural Heritage Program 2004). It is noteworthy that we not only detected them in all four drainages that we surveyed, but that we detected them breeding at $25 \%$ of the sites surveyed in 2004. This is especially encouraging given apparent declining trends for this species elsewhere in western Montana during that last 50 years and region wide detection of breeding at only $2-5 \%$ of sites surveyed in recent years (Maxell 2000, 2004; Maxell et al. 2003; Werner et al. 2004).

Factors affecting breeding toads in western Montana and the sites they use for breeding are not entirely clear. However, there is growing evidence from surveys conducted by the statewide amphibian inventory program, as well as research being conducted in Glacier National Park, that stand replacing fires are beneficial to Western Toads. These fires open up both aquatic and terrestrial habitats to greater solar exposure and may also provide more terrestrial burrows by loosening soils and burning out tree roots (Maxell, 


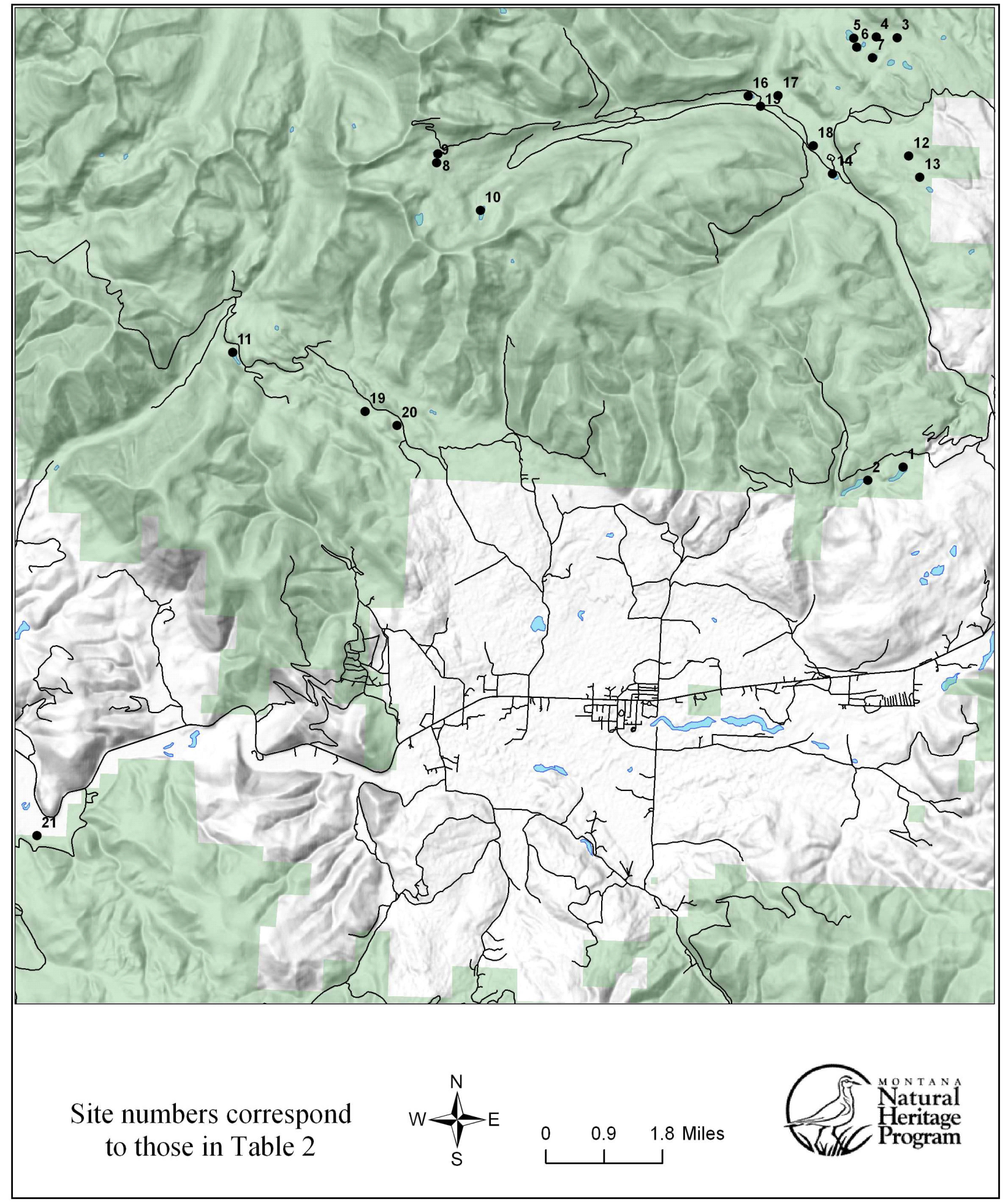

Figure 2. Wetlands surveyed for herpetofauna in 2004 and 2005 
personal observation; Steve Corn and Blake Hossack, Aldo Leopold Wilderness Research Institute, personal communication). Our detections and observations corroborate these findings. We found adult Western Toads in several wetlands within the Copper Creek drainage and Indian Meadows that experienced extensive fire disturbance in 2003. The season when fires occur may be important. Adult Western Toads breed earlier in the year than the typical peak of fire season and are able to seek refuge during autumn fires. Late summer and autumn fires could impact tadpoles and recent metamorphs. However, toads can live 20 years or more once they reach adulthood, a life span that could include many years of complete reproductive failure.

One factor known to affect successful breeding is trampling or similar disturbance. At Upper Keep Cool Lake (site 1 in Figure 2 and Appendix B Table 2) we found recent ATV tracks in the wet meadow as well as within the water within a few feet of where toads were depositing egg strings in 2004 and observed similar evidence of ATV use on our visit in 2005 when the site was virtually dry. Motorized activity in wet meadows could severely affect toad breeding. At known toad breeding sites where the public tends to concentrate, signs could be posted to remind the public that such activity is banned for that specific reason, as well as to protect vulnerable wet meadow and near-shore wetland habitats.

\section{Sensitive Plants \& Communities}

The information below is summarized from notes taken during surveys of late August 2004 and organized by site (Figure 1) in alphabetical order.

- Copper Creek, Upper Drainage: Two pond-centered wetlands were inventoried near the headwaters of Copper Creek. These depressional wetlands probably resulted from glacial scouring of Belt Series bedrock (primarily argillite) leaving relatively shallow excavations with a somewhat impermeable substrate into which headwaters drain and pond before overflowing. The more southerly of the two ponds has dried significantly (no standing water) from what is portrayed on the Stonewall
Mountain USGS 1:24,000 quadrangle map; the previous six droughty years may have resulted in the mudflat condition that now exists. The lowest portion of the (former) pond is a mudflat dominated by a tussock form of water sedge (Carex aquatilis); tufted hairgrass (Deschampsia cespitosa) is scattered as well. The most conspicuous forb is a species of pussytoes (Antennaria). Exposed gravel and rock, once underwater, forms a concentric zone about the mudflat. The Snow-Talon Fire burned up to the perimeter of the pond but there was no obvious evidence that the wetland vegetation had burned.

The considerably larger, more northerly pond has not suffered any perceptible drawdown and is completely encircled by wetland vegetation. The Snow-Talon Fire burned through all the different vegetation types surrounding the pond with variable effects but was most noticeable in the forested portion of the wetland.

Engelmann spruce - subalpine fir / Claspleaf twistedstalk (Picea engelmannii - Abies lasiocarpa / Streptopus amplexifolius) and Engelmann spruce / field horsetail ( $P$. engelmannii / Equisetum arvense) are the two major plant associations comprising the forested portion of the wetland (less than $1 / 4$ of the ponds perimeter) where water input from upslope feeder streams was concentrated. This highly oxygenated water may explain the presence of trees here and not in other perimeter areas where water is stagnant and oxygen depleted. More than half of the trees, predominantly Engelmann spruce, but including subalpine fir and lodgepole pine (Pinus contorta) were killed by the fire. The undergrowth experienced fire of varying intensities but has responded with vigor, probably due to a post-burn fertilization effect. The undergrowth dominants are arrowleaf ragwort (Senecio triangularis), Canby's licorice-root (Ligusticum canbyi), Trollius laxus (American globeflower), green false hellebore (Veratrum viride), claspleaf twistedstalk, Parnassia fimbriata (fringed grass-of-Parnassus), broadleaf arnica (Arnica 
latifolia), and blue wildrye (Elymus glaucus). Grouse whortleberry (Vaccinium scoparium) and rusty menziesia (Menziesia ferruginea) were scattered on higher ground, often encircling tree bases. A stream through the forested wetland supports a liverwort species on completely submerged stream gravels. The streambank was colonized in large part by Sphagnum squarrosum (and/or S. teres).

The perimeter of the area post fire now is dominated by herbaceous species; however about two thirds of the perimeter appears to have previously been shrub/dwarf-shrubdominated. All shrub species are resprouting, but given only a partial season of post-fire growth, their heights are uniformly less than 2 $\mathrm{dm}$. Prior to the fire about a third of the pond's perimeter was occupied by herbaceous communities dominated by beaked sedge (Carex utriculata) or bluejoint reedgrass (Calamagrostis Canadensis). Shrub communities are dominated by willow (Salix) species, primarily Booth' willow (S. boothii) and to a lesser extent, Tweedy's willow ( $S$. tweedyi) which is confined to beaver (Castor canadensis) workings. Bog laurel (Kalmia polifolia) and rose meadowsweet (= rose spiraea, Spiraea splendens) are minor components. The undergrowth of these shrublands is primarily dominated by beaked sedge and/or water sedge and to a lesser degree bluejoint reedgrass. The shrub communities are on raised areas created by former beaver use. The beaked sedge community ranged from near total dominance by this species to equal mixes of beaked sedge and water sedge and/or bluejoint reedgrass / northern reedgrass $(C$. stricta). Timber oatgrass (Danthonia intermedia), a species typically associated with dry sites, quite unexpectedly was scattered in some saturated areas here. Primary forb species included scentbottle (Platanthera dilatata $=$ Habenaria dilatata), Rocky Mountain groundsel (Packera streptanthifolia $=$ Senecio streptanthifolius), twinleaf bedstraw (Galium bifolium), sticky tofieldia (Tofieldia glutinosa) and elephanthead lousewort
(Pedicularis groenlandica). The primary willow species are Booth's willow and Tweedy's willow; these two species are dominant on old beaver workings, beaked sedge is the dominant herb. A variety of bryophytes, including Aulacomnium palustre, Bryum pseudotriquetrum, Bryum spp., Polytrichum spp. and especially Sphagnum spp. form a rather continuous ground layer.

Fragments of several different community types (1-5 $\mathrm{m}$ along their longest axis) were developed on what appeared to be peat deposits (the depth of peat was not measured, but it is likely that the histic epipedon was of insufficient depth to qualify these sites as peatlands). Sedge tussocks (Carex spp., unidentified due to immature inflorescence) constituted $40-70 \%$ canopy cover. They were dispersed over a substrate that was mostly very shallow standing water with a submerged lawn of mosses. Scorpidium spp. is dominant with Bryum pseudotriquetrum and Aulacomnium palustre common. The provisionally recognized Tweedy's willow / bluejoint reedgrass shrubland, a plant community not described at either the state or national level, occurs in small patches on substrates with better drainage than those supporting other willow communities in this complex. This Tweedy's willow-dominated community occupies essentially the same habitat as the Geyer's willow (Salix geyeriana)/ bluejoint reedgrass shrubland in which Booth's willow is considered an ecological analogue of Geyer's willow for purposes of management oriented classification (Hansen et al. 1995). For tracking diversity it is probably prudent to recognize the Tweedy's willow / bluejoint reedgrass community as unique; it can be lumped with Geyer's willow type for mapping and management purposes.

\section{No sensitive plants were found within these wetlands or in the near vicinity.}

\section{- Copper Creek / North Fork Creek}

Confluence: This wetland complex was near the confluence of Copper Creek with North 
Fork Creek. Just west of the confluence of these creeks is a forested and shrub-dominated wetland that burned at various intensities. The forested plant associations Engelmann spruce / field horsetail and Engelmann spruce / bluejoint reedgrass occur in a complex mosaic with the last named occupying sites lower in the landscape (wetter) and the former occurring in slightly higher positions (by 1-4 dm). In addition to Engelmann spruce, lodgepole pine dominates (or at one time dominated) the overstory and mature subalpine fir is scattered within the drier association. Bluejoint reedgrass forms a particularly lush cover, hypothetically due to a post-burn fertilization effect and the reduced tree canopy; incorporated in this tall grass layer is fringed brome (Bromus ciliatus) and two alien species, redtop (Agrostis gigantea $=A$. alba) and quackgrass (Elymus repens $=$ Agropyron repens). Forbs, including Lyall's angelica (Angelica arguta), giant mountain aster (Canadanthus modestus = Aster modestus), and alpine leafybract aster (Symphyotrichum foliaceum $=$ A. foliaceus , are a modest component of this type with a combined cover of less than $10 \%$ throughout most of the mosaic. Robust populations of the noxious weed Canada thistle (Cirsium arvense) are also present; whether this incursion occurred prior to the fire or following is unknown. Inclusions of diamondleaf willow (Salix planifolia) / beaked sedge are present with the willow reduced to root-crown sprouting following the fire.

A tall willow community existed prior to the fire closer to the confluence. The fire burned over the willows killing them back to the base but virtually all clumps are vigorously root-crown sprouting. The primary plant associations present are Geyer's willow / beaked sedge, Booth's willow / beaked sedge, Booth's willow / bluejoint reedgrass, and diamondleaf willow / beaked sedge. The mix of these vigorously sprouting clumps of the two willows is so complex on a fine scale that distinguishing individual community types is quite pointless (situations like this prompted Hansen et al.
[1995] to declare ecological equivalence of the two willow species, using Geyer's willow as the nominal). The grasses and sedges in the willow complex are also quite lush, forming nearly complete coverage, a condition that can be contrasted with the pre-burn situation where the graminoid and forb components are usually quite inconspicuously mixed between clumps of 10-20 ft tall willows. If one were to categorize the current status of the former willow swamp it would be termed a mosaic of the bluejoint reedgrass and beaked sedge herbaceous plant associations.

\section{No sensitive plant species were found.}

\section{- Copper Creek, Lower Drainage Wetlands:}

A large wetland, perhaps a fen in part, lies about $1 / 4$ mile southeast of the confluence of the Copper Creek and its tributary, North Fork Creek. This feature occupies what is probably a large kettle hole formed during the Pleistocene glaciation. This wetland is fed by subsurface seepage from the main stem of Copper Creek. The whole wetland was consumed with fire of varying intensities. The western-most portion of the wetland looks like an extensive carr (a type of fen with woody species prominent and, like all fens, having at least $30 \mathrm{~cm}$ of peat). The peat depth was not measured but in several places jumping on the surface created pressure waves that could be seen some distance away (typical of the floating mats of fens). This western portion had been burned very thoroughly with the shrub component currently sprouting prolifically but still between 1 and $3 \mathrm{dm}$ tall. It appears that a mix of shrubs was present prior to the burn but now no one species could be recognized as dominant. Present are dwarf birch (Betula nana $=B$. glandulosa), diamondleaf willow, Tweedy's willow, shrubby cinquefoil (Dasiphora floribunda $=$ Potentilla fruticosa = Pentaphylloides floribunda), alderleaf buckthorn (Rhamnus alnifolia) and Engelmann spruce. Most stems of the spruce were killed and not sprouting. Beaked sedge is the dominant herb where these shrubs occur, with herb cover ranging widely from $10 \%$ - 
$80 \%$. Other conspicuous herbs are arrowleaf sweet coltsfoot (Petasites sagittata), largeleaf avens (Geum macrophyllum), small camas (Camassia quamash), alpine leafybract aster, purple marshlocks (Comarum palustre $=$ Potentilla palustre), sticky cinquefoil (Potentilla glandulosa), wetland violet species (Viola spp.), alpine bentgrass (Agrsotis humilis) and Baltic rush (Juncus balticus). Several species of moss, all associated with rich carrs and fens, formed a nearly continuous ground cover. Moss species included (on hummocks) Tomenthypnum nitens, Sphagnum warnstorfii and (in swales, standing water) Scorpidium scorpioides, Limprichtia cossonii (Scorpidium cossonii), Limprichtia revolvens (Scorpidium revolvens), and Calliergon stramineum.

Some areas, especially the eastern end of the wetland, never possessed a woody component [or this woody component occurred in dispersed, burned and formerly robust clumps of Geyer's ( $S$. geryeri) and Drummond's willow ( $S$. drummondii)] Beaked sedge is dominant, although in some places alpine bentgrass is a conspicuous component approaching co-dominance. The ground cover is a lawn of mosses with the following most prominent in declining order: Tomenthypnum nitens, Brachythecium salebrosum (= Brachythecium pseudocollinum), Limprichtia cossonii, and Sphagnum warnstorfii. Conspicuous patches, light green from a distance, are dominated by woolyfruit sedge (Carex lasiocarpa); this community has only a few vascular species including muhly (Muhlenbergia spp.), alpine bentgrass, beaked sedge, alpine leafybract aster, and common camas (C. quamash). Also located in the eastern portion of the complex are extensive areas of fowl bluegrass (Poa palustris), both with and without beaked sedge; this composition along with the scattered patches of Canada thistle could be indicative of past disturbance.

\section{No sensitive vascular plant species were} found here, but a more intensive inventory

\section{of the diverse bryophyte community could} be rewarding.

- Keep Cool Lakes: These ponds have dried to "water weed" colonized mud flats due to the multi-year drought. Silts and clays have settled on a bottom of rounded, stream-worked rock. The mud flat is colonized by patches of buckbean (Menyanthes trifoliata) and various species of pondweed (Potamogeton spp.) and dock (Rumex spp.). Baltic rush (Juncus balticus) is also present and appears to be actively expanding from somewhat isolated patches. Near the inflow there is a moisture/ salinity gradient occupied by four relatively distinct communities. The driest sites are occupied by a nearly monospecific tufted hairgrass type that transitions into a moister tufted hairgrass with a dense sub-canopy of shortawn foxtail (Alopecurus aequalis). A pale false mannagrass (Torreyochloa pallida (Torr.) Church var. pauciflora (formerly Puccinellia pauciflora) type is next then the standing water condition (mostly 3-6 cm deep) supports common spikerush (Eleocharis palustris) in a virtual monoculture with the exception of scattered tussocks of tufted hairgrass and dock.

The pale false mannagrass has a dense undergrowth of needle spikerush (Eleocharis acicularis); a community with this composition has not described for Montana (even as a dominance type) or other states. The substrate for this community appears to have a considerably higher clay content than the other communities and, if this species is similar to others in its genus like $P$. nuttalliana, then this community may reflect an alkaline substrate as well. On the margins of the upper pond (particularly in the area of inflow and nearby to the east and south) is an extensive zone of tufted hairgrass that has been invaded with timothy (Pleum pratense) and Kentucky bluegrass (Poa pratensis); this infestation is heaviest near an ATV trail (Figure 3) branching to the south around the pond. Canada thistle and common mullein (Verbascum thapsus) have also established in this area with Canada 
thistle expanding into the muddy pond fringes.

The ATV track is worn to the point that portions of this tufted hairgrass community have been denuded of vegetation. This track and areas immediately to either side are disturbed creating a prime weed establishment site, especially since the ATVs could also disperse weed seeds (which are abundant in the camping area).

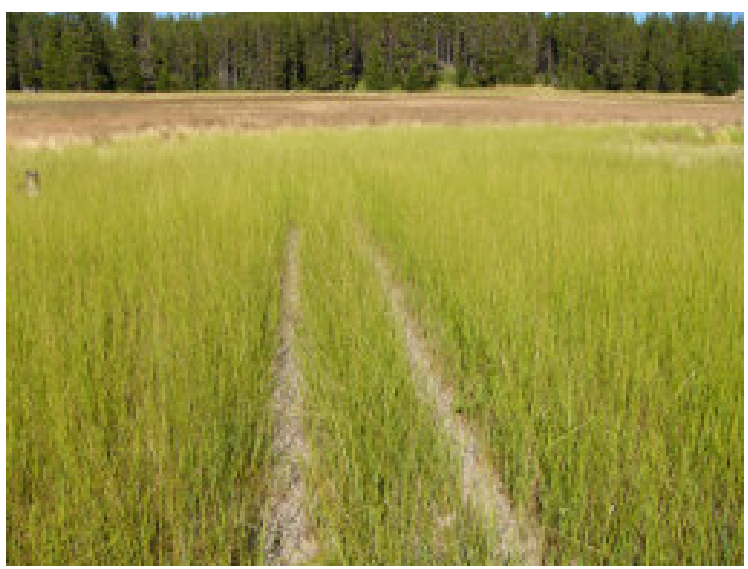

Figure 3. ATV track through Keep Cool Lake wetlands

The ATV track goes on to connect the Upper with Lower Keep Cool Lake. Along this route, timothy has expanded extensively to dominate what could have been a species-rich blue wildrye (Elymus glaucus) dominated meadow. Blue wildrye is now is only scattered at the site. If true, this meadow, although probably not a jurisdictional wetland, could have been a unique meadow type (G2) known (as of 1998) from only California and Oregon (Anderson et al. 1998) and not previously reported from Montana. The ATV trail continues to the perimeter of Lower Keep Cool Lake and, in at least two locations, there were massive disturbances where they had to be extricated from the mud.

There is a small stand of willows at the head of the Lower Lake including Drummond's, Booth's, and Bebb's (S. bebbiana) willows; the vegetation association most similar is Drummond's willow / beaked sedge. Extending to both the north and south of the inlet and arcing around to the west is an extensive and typically species-poor beaked sedge association; common associates are swordleaf rush (Juncus ensifolius), wild bergamot (Monarda fistulosa) and, in standing water, pondweed. Along a more western portion of the northern shore a sort of reverse zonation was encountered where the wettest community, the beaked sedge association, was nearest the upland, giving way centripetally to a common spikerush - tufted hairgrass community, in turn grading to a nearly pure tufted hairgrass association and lastly to a saturated surface with water-filled mini-depressions and much exposed mud that has been uniquely, and virtually monospecifically, colonized by greater creeping spearwort (Ranunculus flammula). Greater creeping spearwort is a common early colonizer of mudflats, especially those with brackish waters, but usually it occurs only as scattered plants, not as the almost continuous cover seen on the drawdown zone of Lower Keep Cool Lake. A visit at one point in time can not determine how ephemeral this condition might be, with continued drought and receding waters to expose mudflats this unique community may persist and expand vegetatively via stolons.

\section{No sensitive vascular species were documented at this local, but a unique community dominated by pale false mannagrass was associated with fine textured substrates.}

- Klondike Creek: A search was conducted both upslope and down (approximately $200 \mathrm{~m}$ in each direction) from the Beaver Creek Rd. crossing. This creek occurs in a V-notch drainage with steep (in excess of 40\%) slopes (at least upslope of the road). The drainage configuration strongly constrained the type of wetlands represented. By far the most prevalent wetland was thinleaf alder (Alnus incana ssp. tenuifolia) dominated and confined to the immediate banks of the stream, only extending about $2 \mathrm{~m}$ away on mini-terraces in those uncommon places where the stream gradient was less. Undergrowth in these thinleaf alder thickets varied from a diversity of 
mesic forbs to virtually no undergrowth (two conditions recognized as separate associations). In some stretches, red-osier dogwood (Cornus sericea) was common, which is indicative of another type of thinleaf alder association. We did not detect abiotic variables that might have been responsible for the compositional differences. Most of the stream was entrenched enough that the bordering type was forested with the subalpine fir - Engelmann spruce / queencup beadlily plant association dominated by spruce, Douglas-fir (Pseudotsuga menziesii), and lodgepole pine. This association is not a wetland but is mesic to hygric in its moisture status and also lacks vegetation indicative of a wetland condition. Very small patches (fragments) of the subalpine fir Engelmann spruce / claspleaf twistedstalk plant association also occur scattered immediately adjacent to the stream or in swales within the very narrow floodplain.

\section{Habitat adjacent to this stream is not conducive to supporting the sensitive plant species we were seeking. Cattle use is also considerable.}

- Lincoln Gulch: This area encompasses the site of the first discovery (mid 1860's) of gold in this portion of the state; the activity, including dredging and pit excavations, continued until the turn of the century. In the ensuing 100+ years the area has largely reforested but the mark of mining is still omnipresent. The steam that courses through the gulch is ephemeral and, with the effects of past dredging, stream modification and downcutting, there is virtually no riparian or wetland communities. Most of the area is potentially dominated by the Engelmann spruce or Douglas-fir series; moister sites support the Engelmann spruce / queencup beadlily association, the Douglas-fir / common snowberry (Symphoricarpos albus) association is on dryer areas. The area probably does not support any jurisdictional wetlands but is clearly subirrigated since the swales support small patches of the Engelmann spruce - subalpine fir / red-osier dogwood association (where lodgepole pine, aspen
[Populus tremuloides] and Douglas-fir are the usual seral dominants). Dogwood canopy cover ranges from about 10 to $40 \%$ and is heavily browsed to a somewhat uniform height of 1 to $1.4 \mathrm{~m}$. The undergrowth is dominated by a short to mid-shrub component dominated by common snowberry (to $80 \%$ canopy cover) and includes creeping barberry (Mahonia repens), common spiraea (Spiraea betulifolia), and russet buffaloberry (Shepherdia canadensis). The forb component of this association is weakly represented and includes sweetscented bedstraw (Galium triflorum), falsegold groundsel (Packera pseudaurea $=$ Senecio pseudaureus), western meadowrue (Thalictrum occidentale), and starry false lilyof-the-valley (Maianthemum stellatum = Smilacina stellata), pink wintergreen (Pyrola asarifolia), and sweetcicely (Osmorhiza berteroi). Graminoids include blue wildrye, roughleaf ricegrass (Oryzopsis asperifolia), and false melic (Schizachne purpurascens). The excavated pit which ranges up to $3 \mathrm{~m}$ in depth contain red-osier dogwood since the slopes and bottoms are near the water-table. Dogwood shoots growing from the center of the deep pits are largely unbrowsed due to difficulty of animal access.

\section{Habitat adjacent to this ephemeral stream are not conducive to supporting the sensitive plant species we were seeking and true wetland communities are not present.}

- Nolo Lakes: Located at about 6,400 and 6,500 feet along the Meadow Creek Pack Trail these two water bodies have a considerably restricted wetland margin, approximately 1 to $5 \mathrm{~m}$ in width. The wettest community is a discontinuous fringe of water sedge that is primarily anchored in a thin unstable mud substrate; some of this community occupies the immediately surrounding stabilized, saturated and highly organic bank. The next drier community is a discontinuous zone typified by a robust sward of bluejoint reedgrass, in which arrowleaf ragwort and green false hellebore are important components. Occupying the most 
extensive and slightly drier wetland habitat is a narrow forested zone dominated by well-spaced Engelmann spruce and very occasional subalpine fir with an undergrowth of scattered rusty menziesia, prickly current (Ribes lacustre), thinleaf or globe huckleberry (Vaccinium membranaceum), with grouse whortleberry in the mid-sized to dwarf shrub layer. Arrowleaf groundsel (Senecio triangularis), green false hellebore, claspleaf twistedstalk, and bluejoint reedgrass are the most abundant herbs, but their individual covers seldom exceeds $10 \%$. The forested plant associations are a mosaic of Engelmann spruce / bluejoint reedgrass on wetter sites and subalpine fir - Engelmann spruce / claspingleaf twistedstalk elsewhere. The latter association has a diversity of wet-site forbs but since rusty menziesia (M. ferruginea) has more than 5\% cover this should be the rusty menziesia phase of this association (Cooper et al. 1985), a phase now elevated to plant association level (NatureServe 2005). The Nolo Lakes expression of this phase matches the modal condition, which is associated with frost pockets and soils with at least seasonally high water tables.

\section{No sensitive plant species were found and Nolo Lakes lack appropriate habitat for these species.}

- Reservoir Lake: This water body appears to lack an outlet and has a water level determined by the prevailing climate. In this period of extended drought, the water level has been drawn down severely leaving a rocky unvegetated shoreline. At the high-watermark tufted hairgrass forms a nearly pure sward encircling the pond and extends over a rocky substrate to the surrounding forest comprised largely of subalpine fir / beargrass (Xerophyllum tenax) or subalpine fir / twinflower (Linnaea borealis) plant associations (Figure 4). Giant mountain aster and alpine leafybract aster, although very scattered, are the next most abundant herbs in the tufted hairgrass meadow type. The fewflower spikerush (Eleocharis quinqueflora $=$ E. pauciflora) community colonizes the few, scattered and small mud flats. A common associate, although occurring with considerably less cover, is Poa secunda (the taxonomic entity once known as $P$. juncifolia, a robust, wetland-associated form of $P$. secunda). Much of the shoreline, particularly the drawdown zone, is being invaded by weedy species including oxeye daisy (Leucanthemum vulgare), white clover (Trifolium repens), timothy, and even spotted knapweed (Centaurea biebersteinii).

\section{No sensitive plant species were found and Reservoir Lake lacks appropriate habitat for the species we are seeking.}

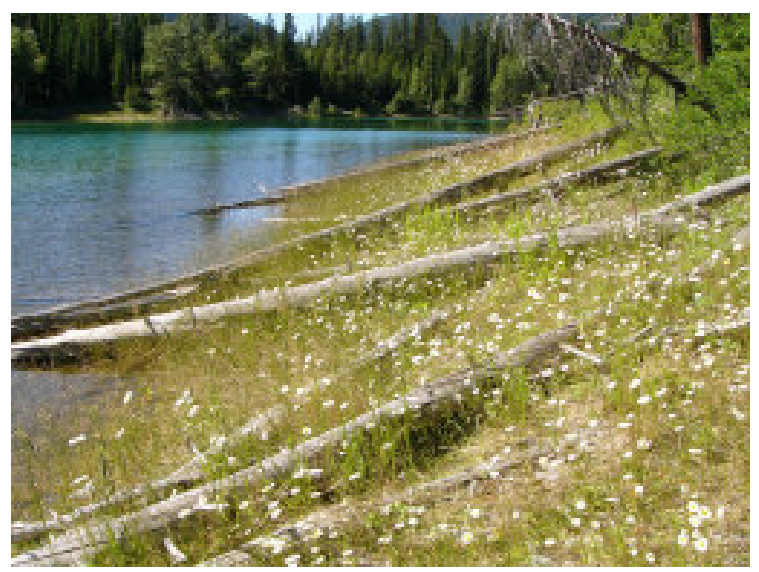

Figure 4. Drawdown zone at Reservoir Lake

- Porcupine Basin: This is not actually a basin but is a reach of the North Fork of Arrastra Creek with a lesser gradient than the adjoining reaches in this vicinity. The area that might be considered a basin is predominantly forested with stands in the riparian portion dominated by Engelmann spruce and subalpine fir.

Shrublands are confined to streamside stringers dominated by thinleaf alder and Sitka alder (Alnus viridis ssp. sinuata). The forested stands that would include true wetlands are of the subalpine fir - Engelmann spruce / rusty menziesia/claspingleaf twistedstalk plant association. Large (approaching a meter in diameter), widely spaced, often with missing mid to upper crown foliage, Engelmann spruce dominate the tree canopy with subalpine fir in the sub-canopy. The cover of rusty menziesia is generally in excess of $70 \%$, mixed with much 
lesser coverages of Sitka alder, thinleaf huckleberry (Vaccinium membranaceum), prickly current and rose spiraea. Beneath the dense shrub canopy forbs are not particularly abundant but are consistently present. Those indicative of high moisture status include claspleaf twistedstalk, green false hellebore (Veratrum viride), arrowleaf ragwort (Senecio triangularis), Lyall's angelica, softleaf sedge (Carex disperma); more generalist forbs included threeleaf foamflower (Tiarella trifoliata), queencup beadlily, Sitka valerian (Valeriana sitchensis), Hitchcock's smooth woodrush (Luzula glabrata var. hitchcockii), northwestern twayblade (Listera caurina), and northern licorice-root. This hygric to hydric association transitions upslope to a mesic forest typified by the Engelmann spruce - subalpine fir / rusty menziesia / queencup beadlily association.

The most unique aspect of this area is the herbdominated community (Figure 5) that occurs just upslope and to the west of the creek occupying deep and subirrigated (and/or seasonally saturated) silty soils derived from alluvium and colluvium (based on vegetation composition alone this would be a wetland but hydrology is unknown and soils were neither mottled nor gleyed). This community would key to the arrowleaf ragwort herbaceous vegetation plant association but the Porcupine Basin representations are considerably more diverse than the modal conception of this association. Although arrowleaf ragwort is generally dominant (30-50\% canopy cover), other forbs have up to $20 \%$ cover including subalpine fleabane (Erigeron peregrinus), Lyall's angelica, green false hellebore, western sweetroot (Osmorhiza occidentalis), sweetscented bedstraw, pioneer violet (Viola glabella), beargrass (Xerophyllum tenax), common cowparsnip (Heracleum maximum), broadleaf arnica, western meadowrue and Virginia strawberry (Fragaria virginiana). Blue wildrye was the dominant graminoid with up to $30 \%$ canopy cover; other graminoids included Pumpelly's brome (Bromus inermis ssp. pumpellianus) and mountain brome
(Bromus marginatus). Despite abundant litter there was considerable bare ground due to the workings of pocket gophers (Thomomys talpoides). The most recently disturbed of these areas were dominated by fireweed (Chamerion angustifolium $=$ Epilobium angustifolium), manyflower stickseed (Hackelia floribunda), western pearly everlasting (Anaphalis margaritacea), and a species of mustard. There was a shrub component but only on the periphery of the herbaceous community including thinleaf huckleberry, prickly current, and rosy spiraea. This meadow complex is probably excellent grizzly bear (Ursus arctos horribilis) habitat.

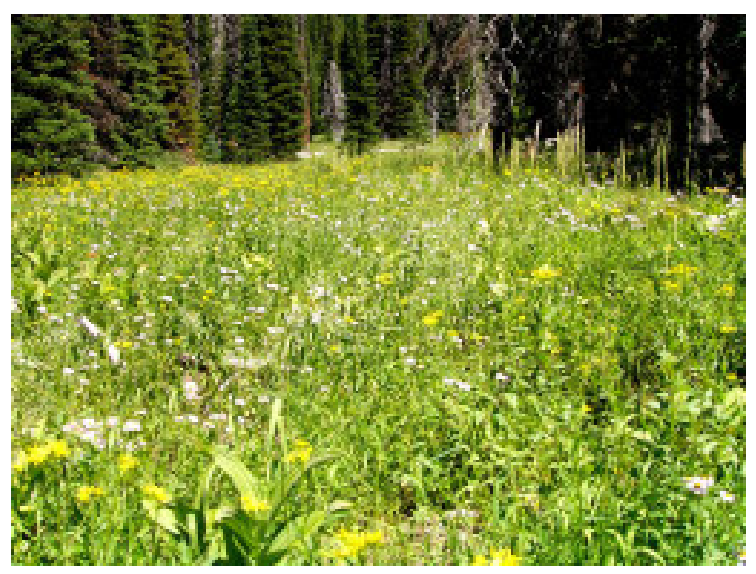

Figure 5. Porcupine Basin wet meadow

Porcupine Basin did not contain any of the sensitive plant species we are seeking, however, the putative occurrence (mature seeds required for positive identification) of northern licorice-root (Ligusticum verticillatum) is thought to be the easternmost documentation of this species, which is usually associated with the more moderate conditions of northern Idaho.

- Theodore Creek: This creek, at least the $400 \mathrm{~m}$ stretch upslope form Beaver Creek Rd. has a moderately steep gradient and is set in a $\mathrm{V}$-notch (relatively narrow, $<20 \mathrm{~m}$ wide, flat bottom) in a forested environment. The only wetland vegetation is confined to streamside stringers of the thinleaf alder community type 
(Hansen et al. 1995) and the subalpine fir Engelmann spruce / claspleaf twistedstalk plant association. Both communities range from about 1 to $5 \mathrm{~m}$ in width and tend to border the subalpine fir / queencup beadlily plant association (Clintonia uniflora phase) on upslope or drier sites of the stream bench. Queencup beadlily, starry false lily-of-the-valley and twinflower dominate the undergrowth and various shrub species, including principally thinleaf huckleberry and thimbleberry (Rubus parviflorus), constitute less than $20 \%$ cover. For extensive stretches the forest, dominated by a variable mix of Engelmann spruce, lodgepole pine, Douglas-fir and subalpine fir, extends right to the creek bank with only the presence of the hydric indicators arrowleaf ragwort, claspleaf twistedstalk, green false hellebore and cowparsnip serving to delimit the narrow wetland zone. Fragments of a relatively rare plant association, Engelmann spruce / softleaf sedge, occur in saturated to the surface small patches (mostly less than $16 \mathrm{~m}^{2}$ ) immediately adjacent to the creek.

No sensitive plants were found, probably due to the lack of appropriate habitat but cattle grazing may also be important.

\section{Conclusions / RECOMMENDATIONS \\ Herpetofauna}

Although Western Toads remain widespread in western Montana they now breed in a relatively small percentage of watersheds and lentic sites across the region. Because population strongholds (i.e., watersheds with a relatively high percent of sites used for breeding) are rare across western Montana, the relatively healthy populations in this region are noteworthy. Perhaps the highest priority for management of herpetofauna in the area would be to initiate a monitoring program for the species with two annual visual encounter surveys conducted at all sites where breeding has been detected. The first survey would target the period of amplexus in order to identify numbers of breeding adults and a second survey would allow monitoring of recruitment through metamorphosis when larvae are about to metamorphose. Together these surveys would assess the effects of post fire habitat succession as well as anthropogenic effects of on and off road vehicle use and recreation, which might require management actions. Furthermore, regular monitoring of Western Toads would also allow all of the other lentic breeding amphibians and aquatic reptiles in the area to be monitored.

Due to the paucity of records in the study area for Rocky Mountain Tailed Frogs, we also recommend systematic surveys of stream habitats in the area for this species. These could either be conducted as focal surveys targeting this species in order to thoroughly understand its distribution and ecological limits in the area, or may be combined with fishery surveys if costs of the first approach are prohibitive. In either case, it is important to submit all observations of this and other species to the Montana Natural Heritage Program so that this information can be placed in the statewide Point Observation Database.

\section{Sensitive Plants \& Communities}

About 30 of the 50 plant associations identified as having Global (G) or State (S) ranks of 3 or less (or undetermined (?)) which potentially occur within the study area were identified (Appendix B Table 1). This represents considerable wetland and riparian diversity for this relatively arid region; additionally most of the wetlands are ecologically intact, although nonnative plants are established in some and are a considerable threat in all wetlands and riparian areas.

One large wetland (Copper Creek, Lower Drainage site) contained an extensive carr, a type of fen, which is a very uncommon community type in Montana. This site also has an extensive bryophyte component and warrants further survey for this taxonomic group. The wetland would make a good candidate for studies of post-fire succession.

At Porcupine Basin we putatively identified the easternmost documentation of Northern licoriceroot, a species more typically found in mesic 
northern Idaho. The lack of seeds for a positive identification suggests that another visit at the appropriate time would be worthwhile.

Keep Cool Lakes has a community type that may have once been a species-rich blue wildrye meadow, a $\mathrm{G} 2$ rank community previously known only from California and Oregon. Nonnative timothy grass now dominates. While this site is still in relatively good ecological condition, it has an ATV trail through the wetland that typifies the range of damage that all accessible wetlands can experience. Nonnative plants were invading along the ATV track, large disturbances occurred where the vehicles were extricated from wet areas, and breeding sites for the Western Toad were only a few feet from the track. ATV use can quickly degrade otherwise intact wetlands if access is easy and not actively discouraged.

\section{Literature Cited}

Anderson, M., P. Bourgeron, M. T. Bryer, R. Crawford, L. Engelking, D. Faber-Langendoen, M. Gallyoun, K. Goodin, D. H. Grossman, S. Landaal, K. Metzler, K. D. Patterson, M. Pyne, M. Reid, L. Sneddon, and A. S. Weakley. 1998. International classification of ecological communities: Terrestrial vegetation of the United States. Volume II. The National Vegetation Classification System: List of types. The Nature Conservancy, Arlington, Virginia, USA.

Association for Biodiversity Information. Dec. 22, 2000. Ecology Access Reporting Tool (EcoART), Version 2.2. Retrieved Nov., 2004 (Disseminated from a no longer functional website; for current information see http:// www.natureserve.org/)

Brunson, R. B. 1952. Recent collections of Bufo boreas boreas from western Montana. Proceedings of the Montana Academy of Sciences 11:17-19.
Cooper, S. V., K. E. Neiman, R. Steele and D. W. Roberts. 1985. Forest habitat types of northern Idaho: A second approximation. USDA Forest Service, Intermountain Research Station. General Technical Report INT-236. Intermountain Research Station, Ogden, UT. 135 pp.

Grossman, D. H., D. Faber-Langendoen, A. S. Weakley, M. Anderson, P. Bourgeron, R. Crawford, K. Goodin, S. Landaal, K. Metzler, K. D. Patterson, M. Pyne, M. Reid, and L. Sneddon. 1998. International classification of ecological communities: Terrestrial vegetation of the United States. Volume I. The National Vegetation Classification System : Development, status, and applications. The Nature Conservancy, Arlington, Virginia, USA

Hansen, P. L., R. D. Pfister, K. Boggs, B. J. Cook, J. Joy and D. K. Hinckley. 1995. Classification and management of Montana's riparian and wetland sites. Miscellaneous Publication 54. Montana Forest and Conservation Experiment Station, School of Forestry, University of Montana, Missoula. 646 pp.

Heyer, W. R., M. A. Donnelly, R. W. McDiarmid, L. C. Hayek, and M. S. Foster, editors. 1994. Measuring and monitoring biological diversity, standard methods for amphibians. Smithsonian Institution Press, Washington, D.C.

Hitchcock, C. L. and A. Cronquist. 1973. Flora of the Pacific Northwest. University of Washington Press, Seattle, WA.

Kartesz, J. T. 1999. A synonymized checklist and atlas with biological attributes for the vascular flora of the United States, Canada, and Greenland. First Edition. In: J. T. Kartesz and C. A. Meacham. Synthesis of the North American Flora. Version 1.0. North Carolina Botanical Garden, Chapel Hill, NC. 
Maxell, B.A. 2000. Management of Montana's amphibians: a review of factors that may present a risk to population viability and accounts on the identification, distribution, taxonomy, habitat use, natural history, and the status and conservation of individual species. Report to USFS Region 1, Order Number 43-0343-0-0224. Missoula, MT: Wildlife Biology Program, University of Montana. $161 \mathrm{pp}$.

Maxell, B. A., J. K. Werner, P. Hendricks, and D. Flath. 2003. Herpetology in Montana: a history, status summary, checklists, dichotomous keys, accounts for native, potentially native, and exotic species, and indexed bibliography. Olympia, WA: Society for Northwestern Vertebrate Biology. Northwest Fauna 5: 1-138.

Maxell, B.A. 2004. Report on amphibian and aquatic reptile inventories conducted on and around the Beaverhead-Deerlodge National Forest 2001-2003. Report to Region 1 Office of the U.S. Forest Service, Beaverhead-Deerlodge National Forest, Montana Department of Fish, Wildlife, and Parks, Montana State Office of the Bureau of Land Management, and Montana Department of Environmental Quality. Montana Cooperative Wildlife Research Unit and Wildlife Biology Program, University of Montana, Missoula, MT. 260 pp.

Montana Natural Heritage Program. 2003. Plant Species of Concern. Montana Natural Heritage Program, Helena, MT. 33 pp.

Montana Natural Heritage Program. 2004. Montana Animal Species of Concern. Montana Natural Heritage Program and Montana Department of Fish, Wildlife, and Parks, Helena, MT. $11 \mathrm{pp}$.

NatureServe. 2002. Ecology Access Reporting Tool (EcoART). Version 2.7, May 2003.

NatureServe. 2005. International Peace Park Vegetation Mapping Project: Vegetation Classification and Local Descriptions of WatertonGlacier International Peace Park (Draft). NatureServe, Boulder, CO. 300 pp.
Olson, D. H., W. P. Leonard, and W. B. Bury, editors. 1997. Sampling amphibians in lentic habitats. Northwest Fauna Number 4.

Werner, J. K., B. A. Maxell, D. Flath, and D.P. Hendricks. 2004. Amphibians and reptiles of Montana. Missoula, MT: Mountain Press Publishing Company. 262p.

Werner, J. K., T. Plummer, and J. Weaselhead. 1998. Amphibians and reptiles of the Flathead Indian Reservation. Intermountain Journal of Sciences 4:33-49. 



\section{Appendix A. Global/State Rank Definitions}





\section{Heritage Program Ranks}

The international network of Natural Heritage Programs employs a standardized ranking system to denote global (range-wide) and state status. Species are assigned numeric ranks ranging from 1 to 5, reflecting the relative degree to which they are "at-risk". Rank definitions are given below. A number of factors are considered in assigning ranks - the number, size and distribution of known "occurrences" or populations, population trends (if known), habitat sensitivity, and threat. Factors in a species' life history that make it especially vulnerable are also considered (e.g., dependence on a specific pollinator).

Global Rank Definitions (NatureServe 2003)

G1 Critically imperiled because of extreme rarity and/or other factors making it highly vulnerable to extinction

G2 Imperiled because of rarity and/or other factors making it vulnerable to extinction

G3 Vulnerable because of rarity or restricted range and/or other factors, even though it may be abundant at some of its locations

G4 Apparently secure, though it may be quite rare in parts of its range, especially at the periphery

G5 Demonstrably secure, though it may be quite rare in parts of its range, especially at the periphery

T1-5 Infraspecific Taxon (trinomial) - The status of infraspecific taxa (subspecies or varieties) are indicated by a "T-rank" following the species' global rank

\section{State Rank Definitions}

S1

S2

S3

S4

S5

At high risk because of extremely limited and potentially declining numbers, extent and/or habitat, making it highly vulnerable to extirpation in the state At risk because of very limited and potentially declining numbers, extent and/or habitat, making it vulnerable to extirpation in the state

S3 Potentially at risk because of limited and potentially declining numbers, extent and/or habitat, even though it may be abundant in some areas

S4 Uncommon but not rare (although it may be rare in parts of its range), and usually widespread. Apparently not vulnerable in most of its range, but possibly cause for long-term concern Common, widespread, and abundant (although it may be rare in parts of its range). Not vulnerable in most of its range

\section{COMBination RANKS}

G\#G\# or S\#S\# Range Rank-A numeric range rank (e.g., G2G3) used to indicate uncertainty about the exact status of a taxon

\section{QUALIFIERS}

NR

Not ranked

Questionable taxonomy that may reduce conservation priority-Distinctiveness of this entity as a taxon at the current level is questionable; resolution of this uncertainty may result in change from a species to a subspecies or hybrid, or inclusion of this taxon in another taxon, with the resulting taxon having a lower-priority (numerically higher) conservation status rank 
Presumed Extinct-Species believed to be extinct throughout its range. Not located despite intensive searches of historical sites and other appropriate habitat, and virtually no likelihood that it will be rediscovered

H Possibly Extinct-Species known from only historical occurrences, but may never-theless still be extant; further searching needed

Unrankable - Species currently unrankable due to lack of information or due to substantially conflicting information about status or trends

HYB Hybrid-Entity not ranked because it represents an interspecific hybrid and not a species

Inexact Numeric Rank-Denotes inexact numeric rank

$\mathrm{C}$

Captive or Cultivated Only-Species at present is extant only in captivity or cultivation, or as a reintroduced population not yet established

Accidental-Species is accidental or casual in Montana, in other words, infrequent and outside usual range. Includes species (usually birds or butterflies) recorded once or only a few times at a location. A few of these species may have bred on the one or two occasions they were recorded

Z Zero Occurrences-Species is present but lacking practical conservation concern in Montana because there are no definable occurrences, although the taxon is native and appears regularly in Montana

Potential-Potential that species occurs in Montana but no extant or historic occurrences are accepted

R Reported-Species reported in Montana but without a basis for either accepting or rejecting the report, or the report not yet reviewed locally. Some of these are very recent discoveries for which the program has not yet received first-hand information; others are old, obscure reports

SYN Synonym - Species reported as occurring in Montana, but the Montana Natural Heritage Program does not recognize the taxon; therefore the species is not assigned a rank

A rank has been assigned and is under review. Contact the Montana Natural Heritage Program for assigned rank

B Breeding - Rank refers to the breeding population of the species in Montana 


\section{Appendix B. Tables}



Table 1. Inventory Targets for Plant Species of Concern and Highly Ranked Plant Communities*

\begin{tabular}{|c|c|c|c|c|}
\hline Scientific Name & Common Name & $\begin{array}{c}\text { Global } \\
\text { Rank }\end{array}$ & $\begin{array}{l}\text { State } \\
\text { Rank }\end{array}$ & $\begin{array}{c}\text { Noted in } \\
\text { survey }\end{array}$ \\
\hline \multicolumn{5}{|c|}{ Potentially Occurring Plant Species of Concern (alphabetically arranged by latin binomial) } \\
\hline Carex chordorrihiza & Creeping Sedge & G5 & S2 & $\mathrm{N}$ \\
\hline Carex idahoa & Idaho Sedge & G2Q & S2 & $\mathrm{N}$ \\
\hline Carex livida & Pale Sedge & G5 & S3 & $\mathrm{N}$ \\
\hline Carex rostrata & Beaked Sedge & G5 & S1 & $\mathrm{N}$ \\
\hline Cypripedium fasciculatum & Clustered Lady's-slipper & G4 & S2 & $\mathrm{N}$ \\
\hline Cypripedium parviflorum & Small Yellow Lady's-slipper & G5 & S2S3 & $\mathrm{N}$ \\
\hline Cypripedium passerinum & Sparrow's-egg Lady's-slipper & G4G5 & S2 & $\mathrm{N}$ \\
\hline Drosera anglica & English Sundew & G5 & S2 & $\mathrm{N}$ \\
\hline Drosera linearis & Linear-leaved Sundew & G4 & S1 & $\mathrm{N}$ \\
\hline Epipactis gigantea & Giant Helleborine & G3G4 & S2 & $\mathrm{N}$ \\
\hline Kalmia polifolia & Pale Laurel & G5 & S1 & $\mathrm{N}$ \\
\hline Lycopodium inundatum & Northern Bog Clubmoss & G5 & S1 & $\mathrm{N}$ \\
\hline Scirpus cespitosus & Tufted Club-rush & G5 & S2 & $\mathrm{N}$ \\
\hline Utricularia intermedia & Flat-leaved Bladderwort & G5 & S1 & $\mathrm{N}$ \\
\hline \multicolumn{5}{|c|}{ Potentially Occurring Wetland/Riparian Plant Communities with $G$ or $S$ Rank of 3 or less, or $S=$ ? } \\
\hline Abies lasiocarpa / Oplopanax horridus Forest & Subalpine fir / Devil's-club Forest & G3 & S2 & $\bar{Y}$ \\
\hline Abies lasiocarpa / Streptopus amplexifoliusForest & Subalpine fir / Claspleaf twistedstalk Forest & G4 & S3 & $\mathrm{Y}$ \\
\hline Abies lasiocarpa / Actaea rubra Forest & Subalpine fir / Baneberry Forest & G4? & S2 & $\mathrm{Y}$ \\
\hline Alnus incana - Betula occidentalis Shrubland & Mountain alder - Water birch Shrubland & G2G3 & S? & $\mathrm{N}$ \\
\hline Alnus incana / Calamagrostis canadensis Shrubland & Mountain alder / Bluejoint reedgrass Shrubland & G3Q & S3Q & $\mathrm{N}$ \\
\hline Alnus incana / Carex spp. Shrubland & Mountain alder / Sedge spp. Shrubland & G3 S? & G3 S? & $\mathrm{N}$ \\
\hline Alnus incana / Cornus sericea Shrubland & Mountain / Red-osier dogwood Shrubland & G3Q & S? & $\mathrm{Y}$ \\
\hline Alnus incana / Equisetum arvense Shrubland & Mountain alder / Field horsetail Shrubland & G3 & S? & $\mathrm{N}$ \\
\hline Alnus incana Mesic Forbs Shrubland & Mountain alder / Mesic Forbs Shrubland & G3 & S? & $\mathrm{Y}$ \\
\hline Alnus incana Shrubland & Mountain alder Shrubland & G?Q & S3 & $\bar{Y}$ \\
\hline Alnus viridis ssp. sinuata / Athyrium filix- femina Shrubland & Sitka alder / Lady fern Shrubland & G3G4 & S? & $\mathrm{N}$ \\
\hline Alnus viridis ssp. sinuata Shrubland [Provisional] & Sitka Alder Shrubland & G?Q & S2 & $\mathrm{N}$ \\
\hline Betula glandulosa / Carex cusickii Shrubland & Bog birch / Cusick's sedge Shrubland & & S3 & $\mathrm{N}$ \\
\hline Betula occidentalis - Pentaphylloides floribunda Shrubland & Water birch - Shrubby cinquefoil Shrubland & G2Q S? & G2QS? & $\mathrm{N}$ \\
\hline Betula occidentalis / Cornus sericea Shrubland & Water birch / Red-osier dogwood Shrubland & G3? & S? & $\mathrm{N}$ \\
\hline Betula occidentalis Shrubland & Water birch Shrubland & G3Q & S3 & $\bar{N}$ \\
\hline Carex buxbaumii Herbaceous Vegetation & Buxbaum's sedge Wet Meadow & G3 & S3 & $\mathrm{N}$ \\
\hline Carex lanuginosa Herbaceous Vegetation & Woolly sedge Herbaceous Vegetation & G3 & S? & $\mathrm{N}$ \\
\hline Carex limosa Herbaceous Vegetation & Mud sedge Herbaceous Vegetation & G2 & S2 & $\mathrm{N}$ \\
\hline Carex simulata Herbaceous Vegetation & Analogue sedge Herbaceous Vegetation & G4 & S3 & $\mathrm{N}$ \\
\hline Cornus sericea Shrubland [Provisional] & Red osier dogwood Shrubland & G4Q & S3 & $\mathrm{Y}$ \\
\hline Cornus sericea / Galium triflorum Shrubland & $\begin{array}{l}\text { Red osier dogwood / } \\
\text { Sweet-scented bedstraw Shrubland }\end{array}$ & G3? & S? & $\mathrm{N}$ \\
\hline Crataegus douglasii Shrubland & Black hawthorn Shrubland & G2Q & S2 & $\mathrm{N}$ \\
\hline Dasiphora fruticosa ssp. floribunda /Carex spp. Shrubland & Shrubby cinquefoil / sedge spp. Shrubland & G3? & S3 & $\mathrm{Y}$ \\
\hline Dulichium arundinaceum Herbaceous Vegetation & Threeway sedge Herbaceous Vegetation & G3 & S2 & $\mathrm{N}$ \\
\hline Eleocharis quinqueflora Herbaceous Vegetation & Few-flower spikerush Herbaceous Vegetation & G4 & S3 & $\mathrm{Y}$ \\
\hline Eleocharis rostellata Herbaceous Vegetation & Beaked spikerush Herbaceous Vegetation & & S1 & $\mathrm{N}$ \\
\hline Glyceria borealis Herbaceous Vegetation & Northern mannagrass Wet Meadow & G4 & S3 & $\mathrm{N}$ \\
\hline
\end{tabular}


Table 1. Continued.

\begin{tabular}{|c|c|c|c|c|}
\hline Scientific Name & Common Name & $\begin{array}{c}\text { Global } \\
\text { Rank }\end{array}$ & $\begin{array}{l}\text { State } \\
\text { Rank }\end{array}$ & $\begin{array}{c}\text { Noted in } \\
\text { survey }\end{array}$ \\
\hline Phragmites australis Temperate Herbaceous Veg. & Western reed Marsh & G5 & S2 & $\overline{\mathrm{N}}$ \\
\hline Picea engelmannii / Carex disperma Forest & Engelmann spruce / Softleaf sedge Forest & G2 & S? & $\mathrm{Y}$ \\
\hline Picea engelmannii / Cornus sericea Woodland & Engelmann spruce / Red-osier dogwood Wdlnd. & G3 & S3 & $\mathrm{N}$ \\
\hline Picea engelmannii / Equisetum arvense Forest & Engelmann spruce / Field horsetail Forest & G4 S2 & S2 & $\mathrm{Y}$ \\
\hline Picea engelmannii / Galium triflorum Forest & Engelmann spruce / Sweet-scented bedstraw For. & G4 & S? & $\mathrm{Y}$ \\
\hline $\begin{array}{l}\text { Populus balsamifera ssp. trichocarpa / Cornus sericea } \\
\text { Forest }\end{array}$ & Black cottonwood / Red-osier dogwood Forest & G3? & S3? & $\mathrm{N}$ \\
\hline Populus tremuloides / Calamagrostis canadensis Forest & Quaking aspen / Bluejoint reedgrass Forest & G3 & S2 & $\mathrm{N}$ \\
\hline Populus tremuloides / Cornus sericea Forest & Quaking aspen / Red-osier dogwood Forest & G4 & S3 & $\mathrm{N}$ \\
\hline Populus tremuloides / Heracleum maximum Forest & Quaking aspen / Common cowparsnip Forest & G4Q & S2? & $\mathrm{N}$ \\
\hline Pseudotsuga menziesii / Cornus sericea Woodland & Douglas fir / Red-osier dogwood Woodland & G4 & S3 & $\mathrm{N}$ \\
\hline Salix candida / Carex lasiocarpa Shrubland & Hoary willow / Slender sedge Shrubland & & S? & $\mathrm{N}$ \\
\hline Salix candida / Carex utriculata Shrubland & Hoary willow / Beaked sedge Shrubland & G3 & S3 & $\mathrm{N}$ \\
\hline $\begin{array}{l}\text { Salix drummondiana / Calamagrostis canadensis } \\
\text { Shrubland }\end{array}$ & $\begin{array}{l}\text { Drummond's willow / } \\
\text { Bluejoint reedgrass Shrubland }\end{array}$ & G3 & S? & $\mathrm{Y}$ \\
\hline Salix geyeriana / Carex aquatilis Shrubland & Geyer's willow / Aquatic sedge Shrubland & G3 & S? & $\bar{Y}$ \\
\hline Salix geyeriana / Deschampsia cespitosa Shrubland & Geyer willow / Tufted hairgrass Shrubland & G4 & S3 & $\mathrm{Y}$ \\
\hline Salix geyeriana / Mesic Graminoids Shrubland & Geyer's willow / Mesic Graminoid Shrubland & G3 & S? & $\mathrm{Y}$ \\
\hline Salix planifolia / Calamagrostis canadensis Shrubland & Planeleaf willow / Bluejoint reedgrass Shrubland & G4 & S? & $\mathrm{N}$ \\
\hline Salix planifolia / Carex aquatilis Shrubland & Planeleaf willow / Aquatic sedge Shrubland & G5 & S3 & $\mathrm{N}$ \\
\hline Salix planifolia / Carex scopulorum Shrubland & $\begin{array}{l}\text { Planeleaf willow / } \\
\text { Holm's Rocky Mountain Sedge Shrubland }\end{array}$ & G3 & S? & $\mathrm{N}$ \\
\hline Salix planifolia / Carex utriculata Shrubland & Planeleaf willow / beaked sedge Shrubland & G1 & S? & $\mathrm{N}$ \\
\hline Salix wolfii / Deschampsia cespitosa Shrubland & Wolf willow / tufted hairgrass Shrubland & G3 & S3 & $\mathrm{N}$ \\
\hline Senecio triangularis Herbaceous Vegetation & Arrowleaf ragwort Herbaceous Vegetation & G5? & S3? & $\mathrm{N}$ \\
\hline Spiraea douglasii Shrubland & Rose spiraea Shrubland & G5 & S2 & $\mathrm{Y}$ \\
\hline
\end{tabular}

* Communities without ranks are those recently described for Montana and not yet ranked. 
Table 2. Amphibian and reptile species detected during wetland site surveys. Heritage Program surveys were conducted in June and September 2004 and July 2005. Other observations at these sites in preceding years are included for reference. Site numbers correspond to those shown in figures.

\begin{tabular}{|c|c|c|c|c|c|c|}
\hline $\begin{array}{l}\text { Site } \\
\text { No. }\end{array}$ & Site Name & $\begin{array}{c}\text { Township Range } \\
\text { Section } \\
\text { (elevation) }\end{array}$ & Date & $\begin{array}{c}\text { Lead } \\
\text { Surveyor \& } \\
\text { Duration } \\
\text { (hr:min) }\end{array}$ & $\underset{\mathrm{a}}{\text { Species }}$ & Comments \\
\hline \multirow[t]{2}{*}{1} & Upper Keep Cool Lake & $\begin{array}{c}\text { T15NR8W S34NWSE } \\
(4980 \mathrm{ft})\end{array}$ & $6 / 1 / 2004$ & $\begin{array}{c}\text { Paul Hendricks } \\
3: 10 \\
\end{array}$ & $\begin{array}{l}\text { BUBO } \\
\text { RALU }\end{array}$ & $\begin{array}{l}3 \text { ad., } 6 \text { egg strings } \\
5 \text { ad., } 17 \text { juv., } 1 \text { tadpole }\end{array}$ \\
\hline & & & $7 / 29 / 2005$ & $\begin{array}{c}\text { Bryce Maxell } \\
0: 57\end{array}$ & $\begin{array}{l}\text { RALU } \\
\text { THSI }\end{array}$ & $\begin{array}{l}1 \text { ad. } \\
1 \text { ad. }\end{array}$ \\
\hline 2 & Lower Keep Cool Lake & $\begin{array}{c}\text { T15NR8W S34SWSW } \\
(4940 \mathrm{ft})\end{array}$ & $6 / 1 / 2004$ & $\begin{array}{c}\text { Paul Hendricks } \\
\text { 2:00 } \\
\end{array}$ & $\begin{array}{l}\text { RALU } \\
\text { THSI } \\
\end{array}$ & $\begin{array}{l}6 \text { ad. } \\
1 \text { ad. }\end{array}$ \\
\hline \multirow[t]{2}{*}{3} & Indian Meadows pond 1 & $\begin{array}{c}\text { T16NR8W S34NENW } \\
(6080 \mathrm{ft})\end{array}$ & $6 / 2 / 2004$ & $\begin{array}{c}\text { Paul Hendricks } \\
1: 40 \\
\end{array}$ & $\begin{array}{l}\text { BUBO } \\
\text { RALU }\end{array}$ & $\begin{array}{l}1 \text { ad., } 800+\text { larvae } \\
2 \text { juv. }\end{array}$ \\
\hline & & & $7 / 29 / 2005$ & $\begin{array}{c}\text { Bryce Maxell } \\
0: 10\end{array}$ & $\begin{array}{l}\text { AMMA } \\
\text { RALU }\end{array}$ & $\begin{array}{l}\leq 100 \text { larvae } \\
2 \text { metamorphs }\end{array}$ \\
\hline \multirow[t]{2}{*}{4} & Indian Meadows pond 2 & $\begin{array}{c}\text { T16NR8W S34NWNW } \\
(6065 \mathrm{ft})\end{array}$ & $6 / 2 / 2004$ & $\begin{array}{l}\text { Paul Hendricks } \\
1: 10\end{array}$ & BUBO & 1 ad. (calling) \\
\hline & & & $7 / 29 / 2005$ & $\begin{array}{c}\text { Bryce Maxell } \\
0: 09 \\
\end{array}$ & BUBO & 200+ metamorphs \\
\hline \multirow[t]{2}{*}{5} & Indian Meadows pond 3 & $\begin{array}{l}\text { T16NR8W S33NWNE } \\
(6040 \mathrm{ft})\end{array}$ & $6 / 2 / 2004$ & $\begin{array}{c}\text { Paul Hendricks } \\
1: 40\end{array}$ & $\begin{array}{l}\text { BUBO } \\
\text { RALU }\end{array}$ & $\begin{array}{l}4 \text { ad. (pair amplexed) } \\
1 \text { subad. }\end{array}$ \\
\hline & & & $7 / 29 / 2005$ & $\begin{array}{c}\text { Bryce Maxell } \\
0: 56\end{array}$ & $\begin{array}{l}\text { AMMA } \\
\text { RALU }\end{array}$ & $\begin{array}{l}3 \text { larvae } \\
2 \text { juv. }\end{array}$ \\
\hline 6 & Indian Meadows pond 4 & $\begin{array}{c}\text { T16NR8W S33SWNE } \\
(6020 \mathrm{ft})\end{array}$ & $6 / 2 / 2004$ & $\begin{array}{c}\text { Paul Hendricks } \\
0: 50 \\
\end{array}$ & RALU & 3 juv., $10+$ larvae \\
\hline 7 & Indian Meadows pond 5 & $\begin{array}{c}\text { T16NR8W S34SWNW } \\
(5950 \mathrm{ft})\end{array}$ & $6 / 2 / 2004$ & $\begin{array}{c}\text { Paul Hendricks } \\
0: 40\end{array}$ & RALU & 2 juv. \\
\hline 8 & Upper Copper Lake & $\begin{array}{c}\text { T15NR9W S4SWSW } \\
(7220 \mathrm{ft})\end{array}$ & $6 / 3 / 2004$ & $\begin{array}{c}\text { Paul Hendricks } \\
\text { 2:00 }\end{array}$ & $\begin{array}{l}\text { AMMA } \\
\text { RALU }\end{array}$ & $\begin{array}{l}1 \text { ad., } 4 \text { egg masses } \\
3 \text { ad., } 9 \text { juv. }\end{array}$ \\
\hline 9 & Upper Copper Lake pond & $\begin{array}{c}\text { T15NR9W S9NENW } \\
(7220 \mathrm{ft})\end{array}$ & $6 / 3 / 2004$ & $\begin{array}{c}\text { Paul Hendricks } \\
0: 40 \\
\end{array}$ & none & \\
\hline 10 & Lower Copper Lake & $\begin{array}{c}\text { T15NR9W S9SESE } \\
(6860 \mathrm{ft})\end{array}$ & $6 / 3 / 2004$ & $\begin{array}{c}\text { Paul Hendricks } \\
0: 30 \\
\end{array}$ & none & large salmonids \\
\hline \multirow[t]{5}{*}{11} & Reservoir Lake & $\begin{array}{c}\text { T15NR10WS25SWNW } \\
(5470 \mathrm{ft})\end{array}$ & $8 / 31 / 1995$ & $\begin{array}{c}\text { Jim Reichel } \\
\text { Unknown duration }\end{array}$ & none & \\
\hline & & & $9 / 1 / 1996$ & $\begin{array}{c}\text { Bogaert, J. } \\
\text { Unknown duration }\end{array}$ & AMMA & 5 individuals \\
\hline & & & $5 / 23 / 2001$ & $\begin{array}{c}\text { Laura Burns } \\
\text { Unknown duration }\end{array}$ & $\begin{array}{l}\text { AMMA } \\
\text { BUBO }\end{array}$ & $\begin{array}{l}200 \text { individuals, } 1 \text { egg } \\
1 \text { amplexed pair }\end{array}$ \\
\hline & & & $6 / 4 / 2004$ & $\begin{array}{c}\text { Paul Hendricks } \\
\text { 1:00 } \\
\end{array}$ & BUBO & $\begin{array}{l}19 \text { ad., } 2 \text { egg strings } \\
\text { ( } 7 \text { pairs amplexed) }\end{array}$ \\
\hline & & & $7 / 29 / 2005$ & $\begin{array}{c}\text { Bryce Maxell } \\
0: 30\end{array}$ & $\begin{array}{l}\text { AMMA } \\
\text { BUBO } \\
\text { RALU }\end{array}$ & $\begin{array}{l}\leq 10,000 \text { larvae } \\
\leq 100 \text { larvae } \\
1 \text { juv. }\end{array}$ \\
\hline 12 & Unnamed wetland & $\begin{array}{c}\text { T15NR8W S3SWSE } \\
(5600 \mathrm{ft})\end{array}$ & $9 / 8 / 2004$ & $\begin{array}{c}\text { Coburn Currier } \\
0: 50 \\
\end{array}$ & RALU & 1 ad., 10 juv. \\
\hline 13 & Unnamed wetland & $\begin{array}{c}\text { T15NR8W S3SESE } \\
(5630 \mathrm{ft})\end{array}$ & $9 / 8 / 2004$ & $\begin{array}{c}\text { Coburn Currier } \\
0: 20 \\
\end{array}$ & RALU & 3 ad., 29 juv. \\
\hline \multirow[t]{3}{*}{14} & Snowbank Lake & $\begin{array}{c}\text { T15NR8W S9NWNW } \\
(5300 \mathrm{ft})\end{array}$ & $6 / 8 / 2001$ & $\begin{array}{c}\text { Mike Kaiser } \\
\text { Unknown duration }\end{array}$ & BUBO & 1 individual \\
\hline & & & $9 / 8 / 2004$ & $\begin{array}{c}\text { Coburn Currier } \\
0: 50 \\
\end{array}$ & BUBO & $\begin{array}{l}\text { 100s juv., } \\
1000 \text { s larvae }\end{array}$ \\
\hline & & & $7 / 29 / 2005$ & $\begin{array}{c}\text { Bryce Maxell } \\
0: 56 \\
\end{array}$ & $\begin{array}{l}\text { BUBO } \\
\text { THEL }\end{array}$ & $\begin{array}{l}\leq 10,000 \text { larvae } \\
2 \text { ad. }\end{array}$ \\
\hline 15 & Copper Creek small pond & $\begin{array}{l}\text { T15NR8W S5NWNW } \\
(5400 \mathrm{ft})\end{array}$ & $9 / 8 / 2004$ & $\begin{array}{c}\text { Coburn Currier } \\
0: 30 \\
\end{array}$ & BUBO & 1 ad. \\
\hline
\end{tabular}

a AMMA (Ambystoma macrodactylum: long-toed salamander), ASMO (Ascaphus montanus: Rocky Mountain tailed frog), BUBO (Bufo boreas: western toad), RALU (Rana luteiventris: Columbia spotted frog), THEL (Thamnophis elegans: Terrestrial Gartersnake), THSI (Thamnophis sirtalis: common garter snake). 
Table 2. Continued.

\begin{tabular}{|c|c|c|c|c|c|c|}
\hline $\begin{array}{l}\text { Site } \\
\text { No. }\end{array}$ & Site Name & $\begin{array}{c}\text { Township Range } \\
\text { Section } \\
\text { (elevation) }\end{array}$ & Date & $\begin{array}{l}\text { Surveyor and } \\
\text { Duration } \\
\text { (hr:min) }\end{array}$ & Species $^{\mathrm{a}}$ & Comments \\
\hline \multirow[t]{3}{*}{16} & Copper Creek big pond & $\begin{array}{c}\text { T15NR8W S5NWNW } \\
(5400 \mathrm{ft})\end{array}$ & $5 / 24 / 1995$ & $\begin{array}{l}\text { Jim Reichel } \\
\text { Unknown } \\
\text { duration }\end{array}$ & $\begin{array}{l}\text { AMMA } \\
\text { RALU }\end{array}$ & $\begin{array}{l}7 \text { egg masses } \\
1 \mathrm{ad} .\end{array}$ \\
\hline & & & $9 / 8 / 2004$ & $\begin{array}{c}\text { Coburn Currier } \\
1: 10\end{array}$ & $\begin{array}{l}\text { BUBO } \\
\text { RALU }\end{array}$ & $\begin{array}{l}1 \text { ad., } 1 \text { juv. } \\
5 \text { ad., } 12 \text { juv. }\end{array}$ \\
\hline & & & & $\begin{array}{c}\text { Bryce Maxell } \\
0: 46\end{array}$ & $\begin{array}{l}\text { AMMA } \\
\text { BUBO } \\
\text { RALU } \\
\text { THEL }\end{array}$ & $\begin{array}{l}\leq 100 \text { larvae } \\
\leq 100 \text { larvae, } 9 \text { juv. } \\
\leq 100 \text { larvae, } 13 \mathrm{ad} \\
2 \mathrm{ad}\end{array}$ \\
\hline 17 & Copper Creek wetlands & $\begin{array}{c}\text { T15NR8W S5NWNE } \\
(5350 \mathrm{ft})\end{array}$ & $9 / 8 / 2004$ & $\begin{array}{c}\text { Coburn Currier } \\
2: 10\end{array}$ & RALU & $\begin{array}{l}1 \text { ad., } 6 \text { juv., } \\
3 \text { larvae }\end{array}$ \\
\hline 18 & Copper Creek marsh & $\begin{array}{l}\text { T15NR8W S4NWSW } \\
(5340 \mathrm{ft})\end{array}$ & $9 / 9 / 2004$ & $\begin{array}{c}\text { Coburn Currier } \\
0: 30\end{array}$ & RALU & 2 ad. \\
\hline 19 & Yukon Creek & $\begin{array}{l}\text { T15NR9W S29SESW } \\
(5000 \mathrm{ft})\end{array}$ & $9 / 9 / 2004$ & $\begin{array}{c}\text { Coburn Currier } \\
2: 40\end{array}$ & $\begin{array}{l}\text { ASMO } \\
\text { RALU }\end{array}$ & $\begin{array}{l}1 \text { ad., } 29 \text { larvae } \\
3 \text { juv. }\end{array}$ \\
\hline 20 & Klondike Creek & $\begin{array}{c}\text { T15NR9W S32NENE } \\
(4900 \mathrm{ft})\end{array}$ & $9 / 9 / 2004$ & $\begin{array}{c}\text { Coburn Currier } \\
2: 10\end{array}$ & $\begin{array}{l}\text { ASMO } \\
\text { BUBO }\end{array}$ & $\begin{array}{l}21 \text { larvae } \\
1 \text { ad. }\end{array}$ \\
\hline \multirow[t]{5}{*}{21} & Blackfoot Oxbow & T14NR10W S33SWSE & $8 / 25 / 1995$ & $\begin{array}{l}\text { Jim Reichel } \\
\text { Unknown } \\
\text { duration }\end{array}$ & $\begin{array}{l}\text { AMMA } \\
\text { BUBO } \\
\text { RALU }\end{array}$ & $\begin{array}{l}1 \text { larvae } \\
3 \text { metamorphs } \\
10 \text { ad., } 43 \text { juv }\end{array}$ \\
\hline & & & $7 / 6 / 2001$ & $\begin{array}{c}\text { Ryan Killackey } \\
1: 00\end{array}$ & $\begin{array}{l}\text { AMMA } \\
\text { BUBO } \\
\text { RALU } \\
\end{array}$ & $\begin{array}{l}\leq 100 \text { larvae } \\
\leq 100 \text { larvae } \\
\leq 100 \text { larvae, } 1 \text { juv, } 1 \text { ad }\end{array}$ \\
\hline & & & $7 / 9 / 2002$ & $\begin{array}{c}\text { Franz Zikesch } \\
\text { 2:00 }\end{array}$ & $\begin{array}{l}\text { AMMA } \\
\text { BUBO } \\
\text { RALU }\end{array}$ & $\begin{array}{l}\leq 100 \text { larvae } \\
<10,000 \text { larvae } \\
3 \text { juv, } 1 \text { ad. }\end{array}$ \\
\hline & & & $7 / 25 / 2004$ & $\begin{array}{l}\text { Allison Greene } \\
\text { Unknown } \\
\text { duration }\end{array}$ & $\begin{array}{l}\text { BUBO } \\
\text { RALU }\end{array}$ & $\begin{array}{l}30 \text { juv. } \\
1 \text { ad. }\end{array}$ \\
\hline & & & $7 / 28 / 2005$ & $\begin{array}{c}\text { Bryce Maxell } \\
\text { 5:00 }\end{array}$ & $\begin{array}{l}\text { AMMA } \\
\text { BUBO } \\
\text { RALU } \\
\text { THEL }\end{array}$ & $\begin{array}{l}\leq 1,000 \text { larvae } \\
10,000+\text { larvae, } 1,000+ \\
\text { metamorphs, } 1 \text { ad. } \\
\leq 10 \text { larvae, } 5 \text { juv, } 10 \text { ad } \\
1 \text { ad. }\end{array}$ \\
\hline
\end{tabular}

a AMMA (Ambystoma macrodactylum: long-toed salamander), ASMO (Ascaphus montanus: Rocky Mountain tailed frog), BUBO (Bufo boreas: western toad), RALU (Rana luteiventris: Columbia spotted frog), THEL (Thamnophis elegans: Terrestrial Gartersnake), THSI (Thamnophis sirtalis: common garter snake). 


\section{Appendix C. Occurrence Maps of Herpetofauna}





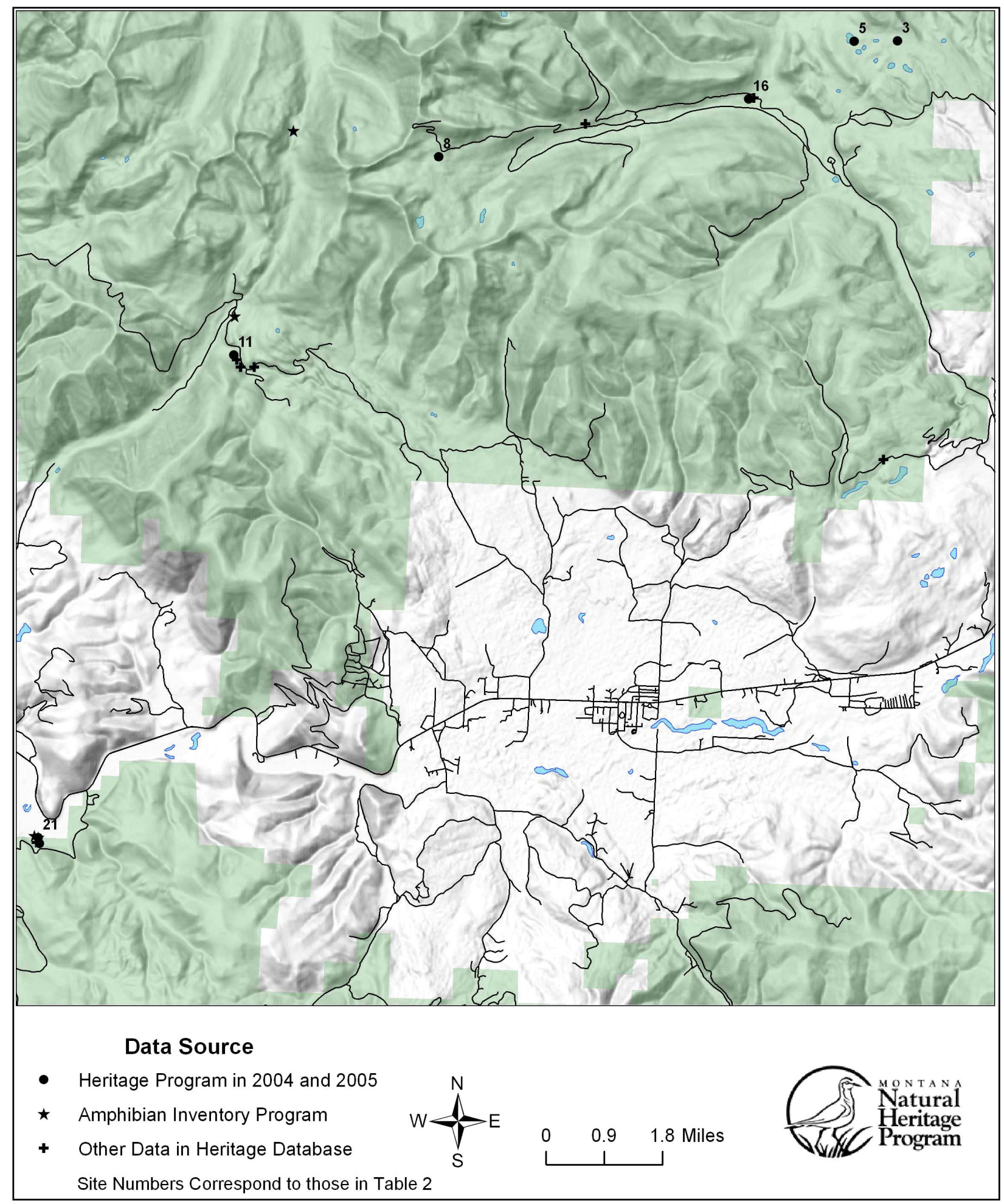

Figure 1. Long-toed Salamander (Ambystoma macrodactylum)

Appendix C - 1 


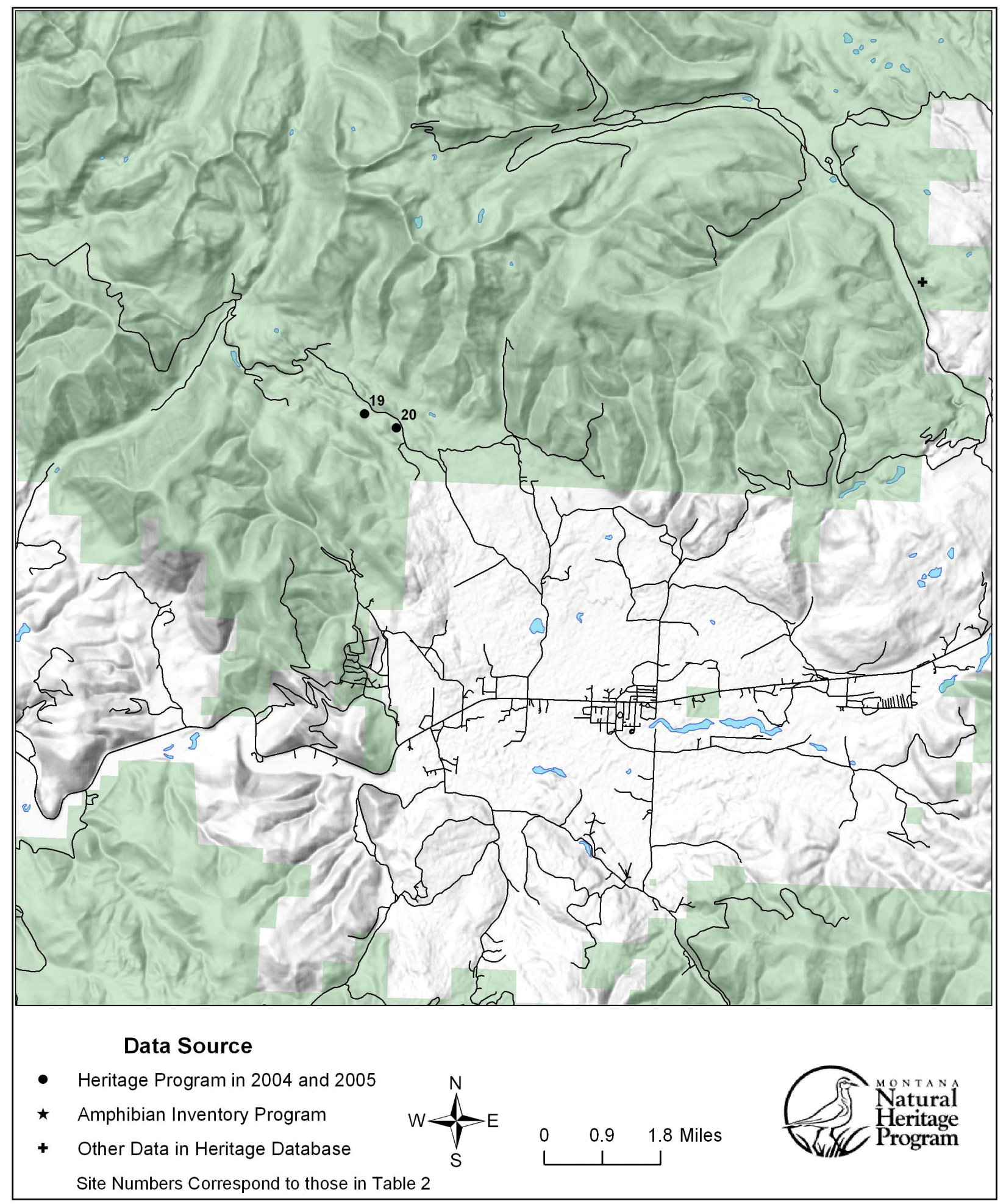

Figure 2. Rocky Mountain Tailed Frog (Ascaphus montanus)

Appendix C - 2 


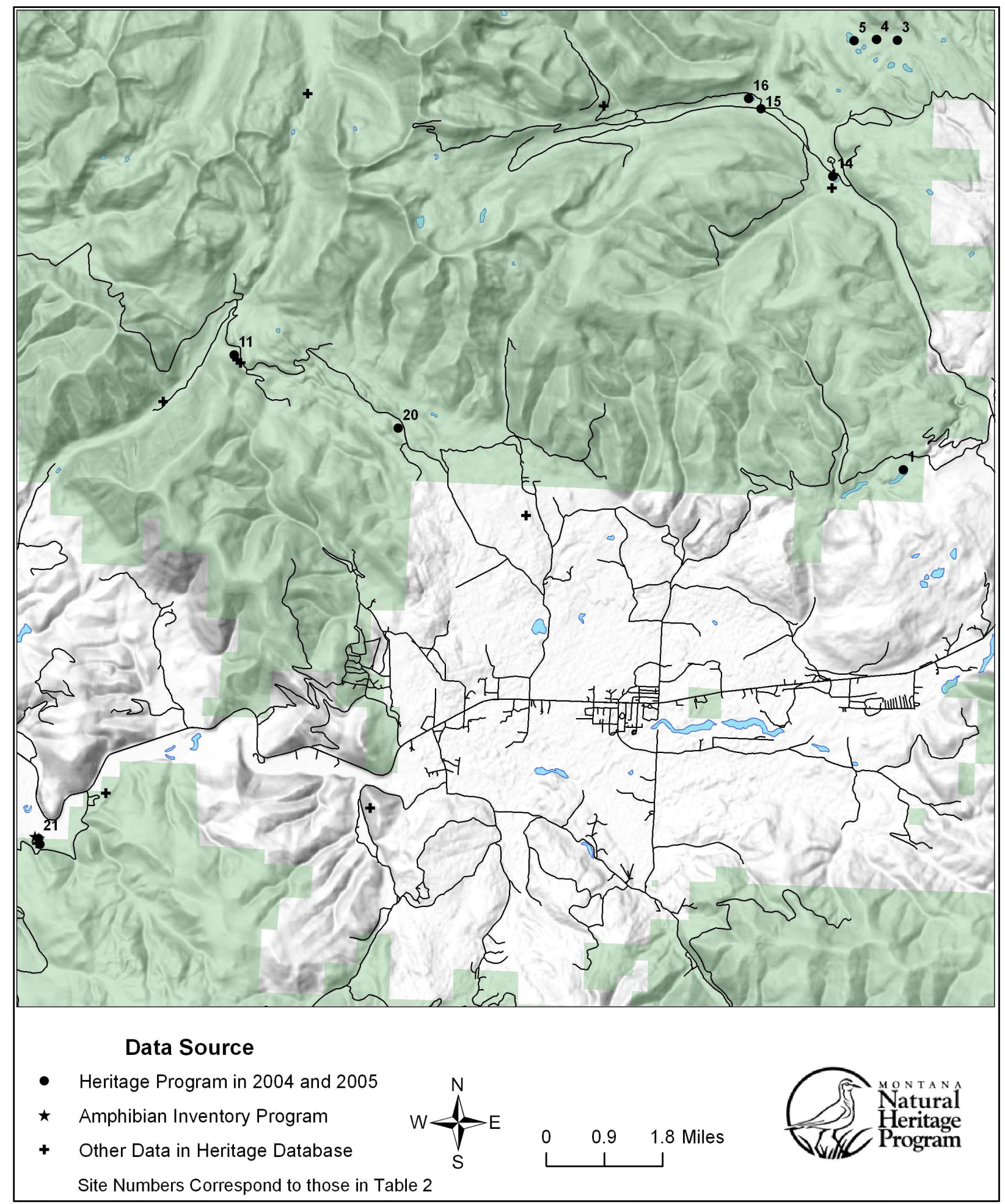

Figure 3. Western Toad (Bufo boreas)

Appendix C - 3 


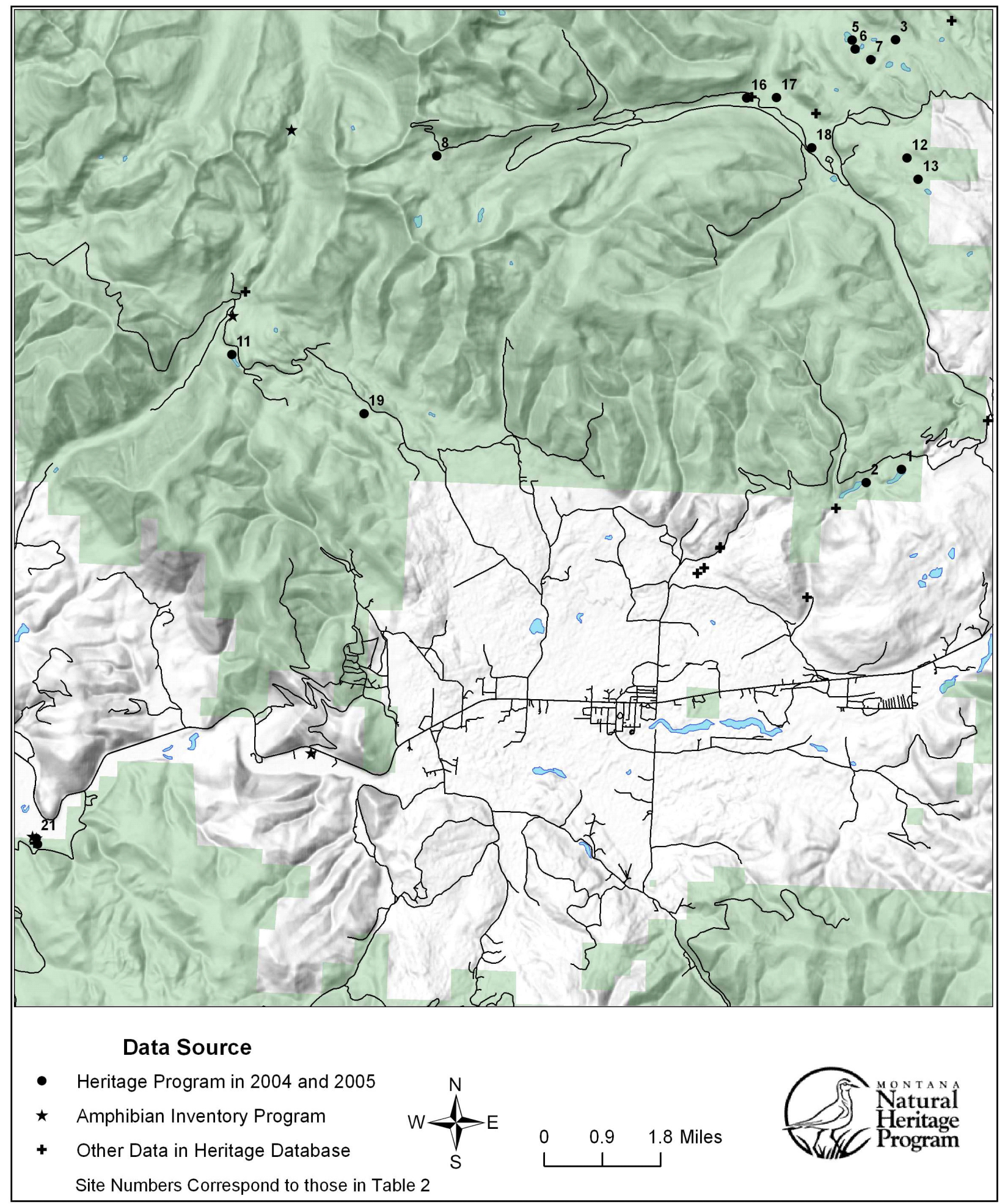

Figure 4. Columbia Spotted Frog (Rana luteiventris)

Appendix C - 4 


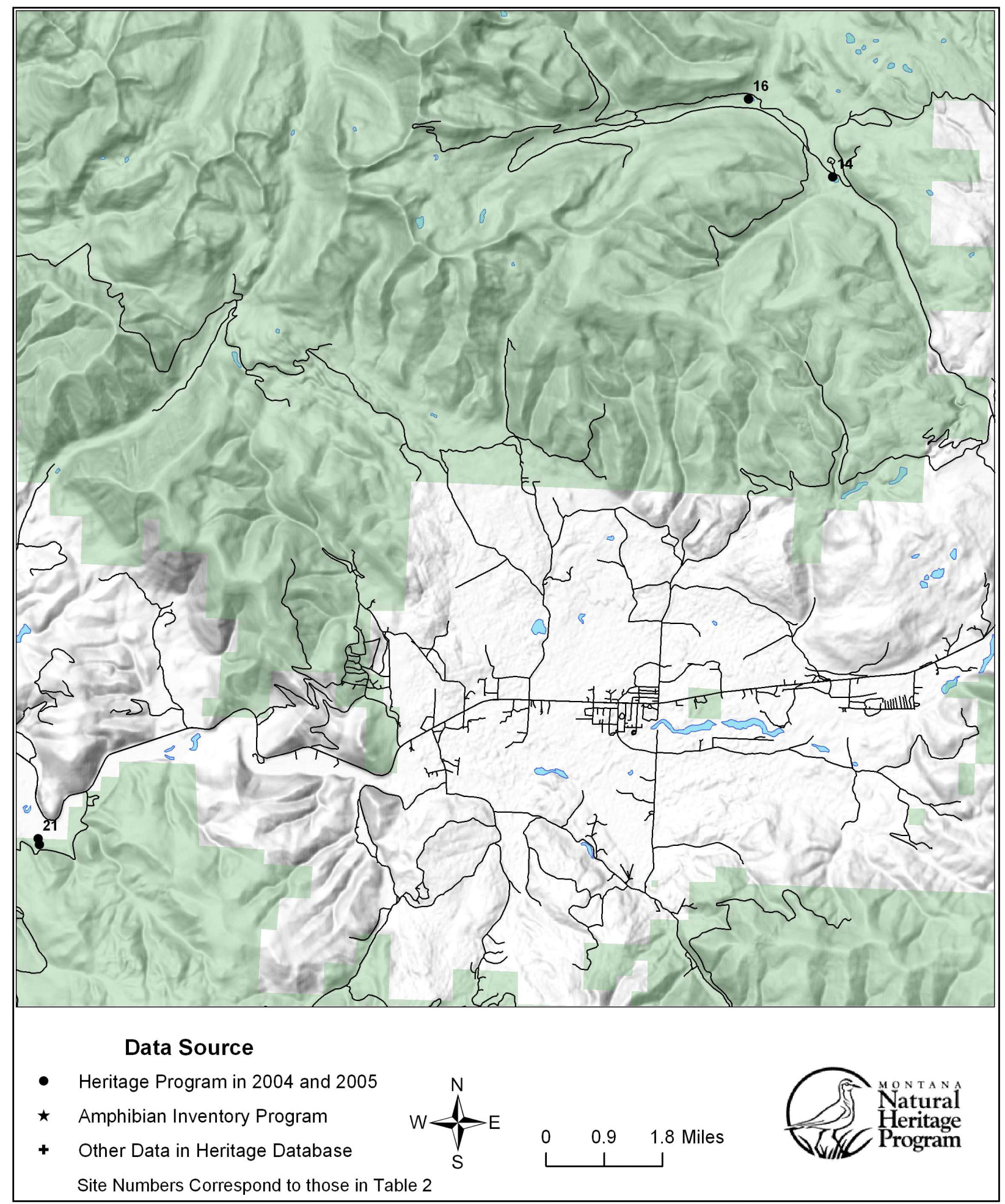

Figure 5. Terrestrial Gartersnake (Thamnophis elegans)

Appendix C - 5 


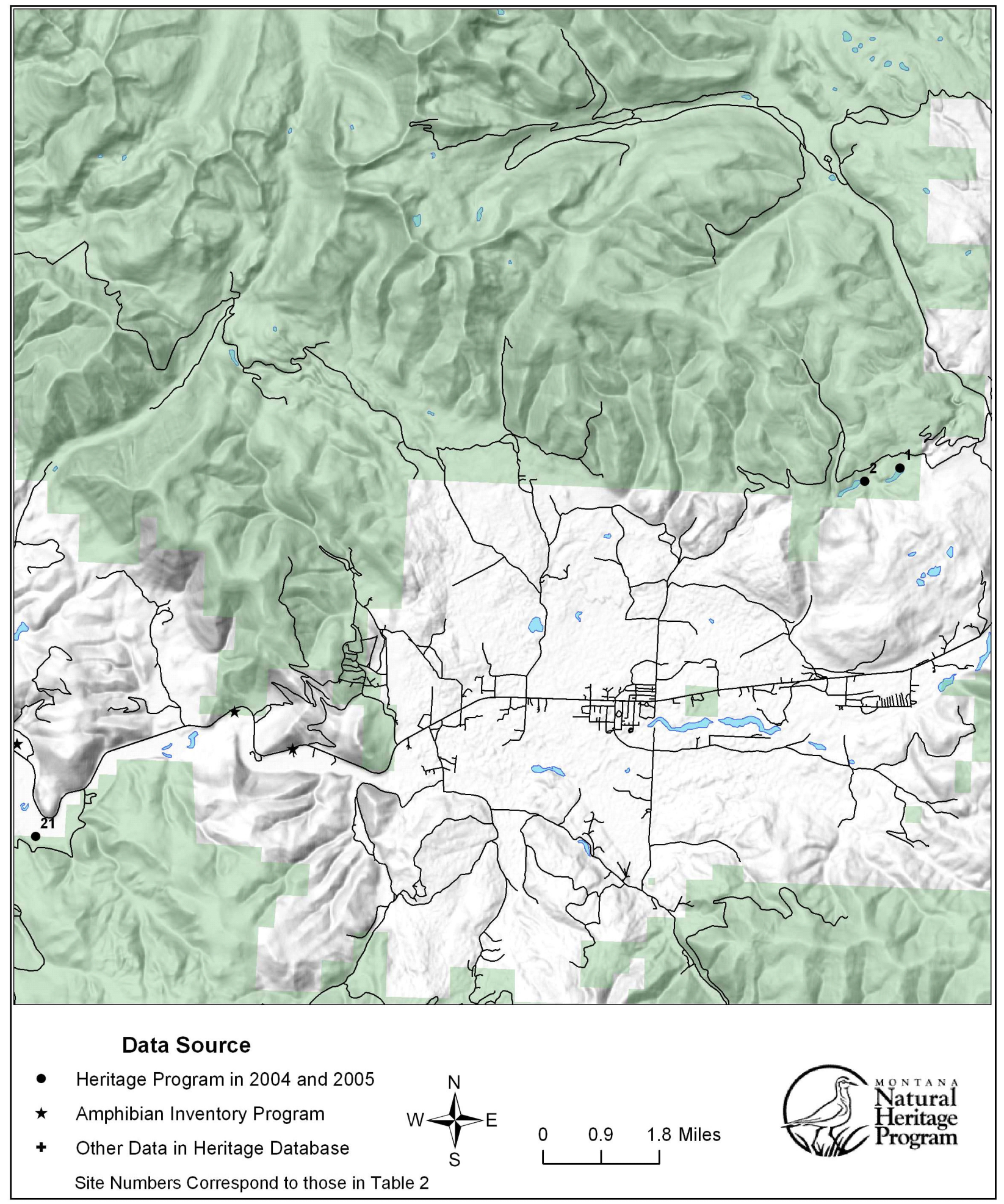

Figure 6. Common Gartersnake (Thamnophis sirtalis)

Appendix C - 6 